\title{
Bacterial DNA repair genes and their eukaryotic homologues: 2. Role of bacterial mutator gene homologues in human disease. Overview of nucleotide pool sanitization and mismatch repair systems ${ }^{\star}$
}

\author{
Katarzyna D. Arczewska ${ }^{\star}$ and Jarosław T. Kuśmierek ${ }^{\bowtie}$ \\ Molecular Biology Department, Institute of Biochemistry and Biophysics, Polish Academy of Sciences, \\ Warszawa, Poland
}

Received: 07 August, 2007; revised: 10 September, 2007 accepted: 19 September, 2007 available on-line: 23 September, 2007

\begin{abstract}
Since the discovery of the first $E$. coli mutator gene, mutT, most of the mutations inducing elevated spontaneous mutation rates could be clearly attributed to defects in DNA repair. MutT turned out to be a pyrophosphohydrolase hydrolyzing 8-oxodGTP, thus preventing its incorporation into DNA and suppresing the occurrence of spontaneous AT $\rightarrow$ CG transversions. Most of the bacterial mutator genes appeared to be evolutionarily conserved, and scientists were continuously searching for contribution of DNA repair deficiency in human diseases, especially carcinogenesis. Yet a human MutT homologue - hMTH1 protein - was found to be overexpressed rather than inactivated in many human diseases, including cancer. The interest in DNA repair contribution to human diseases exploded with the observation that germline mutations in mismatch repair (MMR) genes predispose to hereditary non-polyposis colorectal cancer (HNPCC). Despite our continuously growing knowledge about DNA repair we still do not fully understand how the mutator phenotype contributes to specific forms of human diseases.
\end{abstract}

Keywords: DNA damage, DNA repair, MutT protein, human MutT homologue, mismatch repair, hereditary non-polyposis colorectal cancer

\section{INTRODUCTION}

Maintaining low mutation rates is essential for the cell stability. However, natural isolates of Escherichia coli have been found to have elevated mutation rates (Matic et al., 1997) and strains showing this phenotype are termed mutators. Although the mutator phenotype may have some beneficial effects allowing better adaptation to environmental conditions, it also generates many deleterious and lethal mutations (Funchain et al., 2000).

The first described E. coli mutator gene - mutT1 (Treffers et al., 1954) which specifically increases, from 100 to 10000-fold, the occurrence of AT $\rightarrow$ CG transversions (Yanofsky et al., 1966) was shown to encode MutT pyrophosphohydrolase specifically acting on 8-oxodGTP (Maki \& Sekiguchi, 1992), thus preventing incorporation of this po-

\footnotetext{
${ }^{\star}$ This paper is dedicated to our mentors: David Shugar, Celina Janion, Irena Pietrzykowska, Zofia Zarębska and Daniela Barszcz, scientists from the Institute of Biochemistry and Biophysics Polish Academy of Sciences, who contributed to a great extent to the development in the field of DNA damage, mutagenesis and repair.

Corresponding author: Jarosław Kuśmierek, Institute of Biochemistry and Biophysics, Polish Academy of Sciences, Pawińskiego 5a, 02-106 Warszawa, Poland; tel.: (48 22) 592 3338; e-mail: jareq@ibb.waw.pl

Present address: The Biotechnology Centre, University of Oslo, Gaustadalléen 21,0349 Oslo, Norway.

Abbreviations: (h)MTH1-2, (human) MutT homologue 1-2; 2-oxoA, 8-oxoA and 8-oxoG, 2-oxoadenine, 8-oxoadenine and 8-oxoguanine, respectively, also refers to these oxidized bases in (deoxy)nucleosides and (deoxy)nucleotides; HNPCC, hereditary non-polyposis colorectal cancer; IDL, insertion/deletion loop; MLH1-3, mutL homologue 1-3; MMR, mismatch repair; MSH1-MSH6, MutS homologues 1-6; MSI, microsatellite instability; MutL $\alpha$, MLH1-PMS2 heterodimer; MutS $\alpha$, MSH2-MSH6 heterodimer; MutS $\beta$, MSH2-MSH3 heterodimer; MYH, MutY homologue; NDPK, nucleoside diphosphate kinase; NER, nucleotide excision repair; NSCLC, non-small cell lung cancer; OGG1-2, 8-oxoguanine DNA glycosylase 1-2; PMS1-2, post meiotic segregation protein 1-2; RFC, replication factor C; RPA, replication protein A; SSB, single-stranded DNA binding protein.
} 
tentially mutagenic substrate into DNA. The list of E. coli mutators was extended further by other DNA repair gene products, such as the base excision repair (BER) glycosylases MutM/Fpg and MutY (for details see Krwawicz et al., this issue), mismatch repair (MMR) proteins MutH, MutS and MutL (for details see below), and MutU/UvrD - helicase II engaged in MMR, nucleotide excision repair (NER) (Truglio et al., 2006; for details see Maddukuri et al., this issue), and recombination repair (RR) (for details see Vidakovic et al., 2005; O'Driscoll \& Jeggo, 2006; Nowosielska, this issue). Additionally, Miller (1996) extended the list of E. coli mutators by ung, sodA, dam, $o x y R$, and polA strains defective in uracil-DNA glycosylase, superoxide dismutase, DNA adenine methyltransferase, positive regulator of oxidative damage response, and DNA polymerase I, respectively, but all of them are rather weak mutators and thus are not considered as major E. coli mutators. The list of E. coli mutators is not limited to strains defective in DNA repair, but also includes strains encoding mutated tRNAs, such as mutA and mutC (Slupska et al., 1996), and mutated $3^{\prime} \rightarrow 5^{\prime}$ proofreading $\varepsilon$ subunit of the DNA polymerase III holoenzyme - mutD/dnaQ (Echols et al., 1983), but they are not subject of this review.

Counterparts of bacterial DNA repair proteins have been found in eukaryotic organisms, including humans. Moreover, it has been shown that DNA repair deficiency results in accumulation of DNA damage, which may contribute to aging and development of human diseases, including cancer and neurological diseases (Brooks, 2002; Krokan et al., 2004; Olinski et al., 2007). The present review describes two DNA repair and damage prevention systems - nucleotide pool sanitization and mismatch repair. For an overwiev of the human repair proteins described below see Table 1 .

\section{NUCLEOTIDE POOL DAMAGE AS SOURCE OF MUTATIONS AND ITS PREVENTION BY E. COLI MutT PROTEIN}

Various DNA damaging agents react with nucleic acid bases present not only in DNA (for a review see Krwawicz et al., this issue), but also in precursors for DNA synthesis, i.e. 2'-deoxyribonucleoside-5'-triphosphates (dNTPs). Generally, bases in dNTPs are more easily accessible to damage than bases in DNA, where they are involved in secondary and tertiary DNA as well as chromosomal structures (Topal \& Baker, 1982; Kamiya \& Kasai, 1995). Modified dNTPs may induce mutations, since they are incorporated into DNA by DNA polymerases with an efficiency within the range of $10^{-5}-10^{-2}$ of unmodified dNTPs incorporation (for examples see: Snow et al., 1984; Purmal et al., 1994; Miller et al., 2000; Imoto et al., 2006). In fact, one of the most common oxidative modifications in the dNTP pool - 8-oxodGTP - has been shown to be incorporated almost 24 times more efficiently opposite template A than opposite template $C$ by human polymerase $\beta$ (Miller et al., 2000). Thus, 8-oxodGTP misincorporated opposite A may lead to AT $\rightarrow$ CG transversions (for details see Fig. 1) both in vitro (Pavlov et al., 1994; Minnick et al., 1994) and in vivo (Inoue et al., 1998; Satou et al., 2005).

To prevent 8-oxodGTP incorporation to DNA, $E$. coli cells are equipped with the MutT protein, which was discovered as a nucleoside triphosphate pyrophosphohydrolase dephosphorylating all canonical ribo- and 2'-deoxyribonucleoside-5'-triphosphates to their corresponding 5'-monophosphates and inorganic pyrophosphate $\left(\mathrm{dNTP}+\mathrm{H}_{2} \mathrm{O} \rightarrow \mathrm{dNMP}+\right.$ PPi) (Bhatnagar \& Bessman, 1988; Bhatnagar et al., 1991). Initially, the MutT protein was proposed to prevent the occurrence of $\mathrm{AT} \rightarrow \mathrm{CG}$ transversions by degrading a specific form of dGTP, or dGTP in the syn conformation, which can mispair with A during replication (Akiyama et al., 1989; Bhatnagar et al., 1991). However, the discovery that the MutT protein is over 2000 times more active towards 8-oxodGTP than towards dGTP, has pointed out to its true role (Maki \& Sekiguchi, 1992). Recently it appeared that the MutT protein is also able to efficiently hydrolyze 8-oxodGDP (Ito et al., 2005). 8-OxodGTP and 8-oxodGDP are interconvertible, probably by the actions of nucleoside diphosphate kinase (NDPK) and nucleoside triphosphatase (Hayakawa et al., 1995; Kamiya \& Kasai, 1999). Furthermore, MutT protein also prevents transcriptional errors by dephosphorylation of ribonucleotides 8-oxoGDP and 8-oxoGTP, which otherwise can be incorporated into RNA opposite A present in the DNA template (Taddei et al., 1997; Ito et al., 2005).

A comparison of the amino-acid sequence of the MutT protein with sequences present in databases has revealed similarities with putative products of uncharacterized open reading frames (Orfs) from bacteria to mammals, and also with viral gene products of unknown function. All these similarities were concentrated in the same MutT segment consisting of about 30 amino acids, with six positions containing strictly conserved amino-acid residues. Based on this sequence homology the MutT protein family was distinguished as a family of proteins containing the MutT signature sequence, i.e. $\mathrm{Gx}_{5} \mathrm{Ex}_{7} \mathrm{REUxEEx}_{2} \mathrm{U}$ (where $x$ means any residue and $U$ means a bulky aliphatic or hydrophobic residue, i.e. I, L, V, M, F, $\mathrm{Y}$ or W) (Koonin, 1993). In consequence, functional MutT homologues from Proteus vulgaris and Streptococcus pneumoniae were identified, characterized, and shown to complement the mutator phenotype of the 

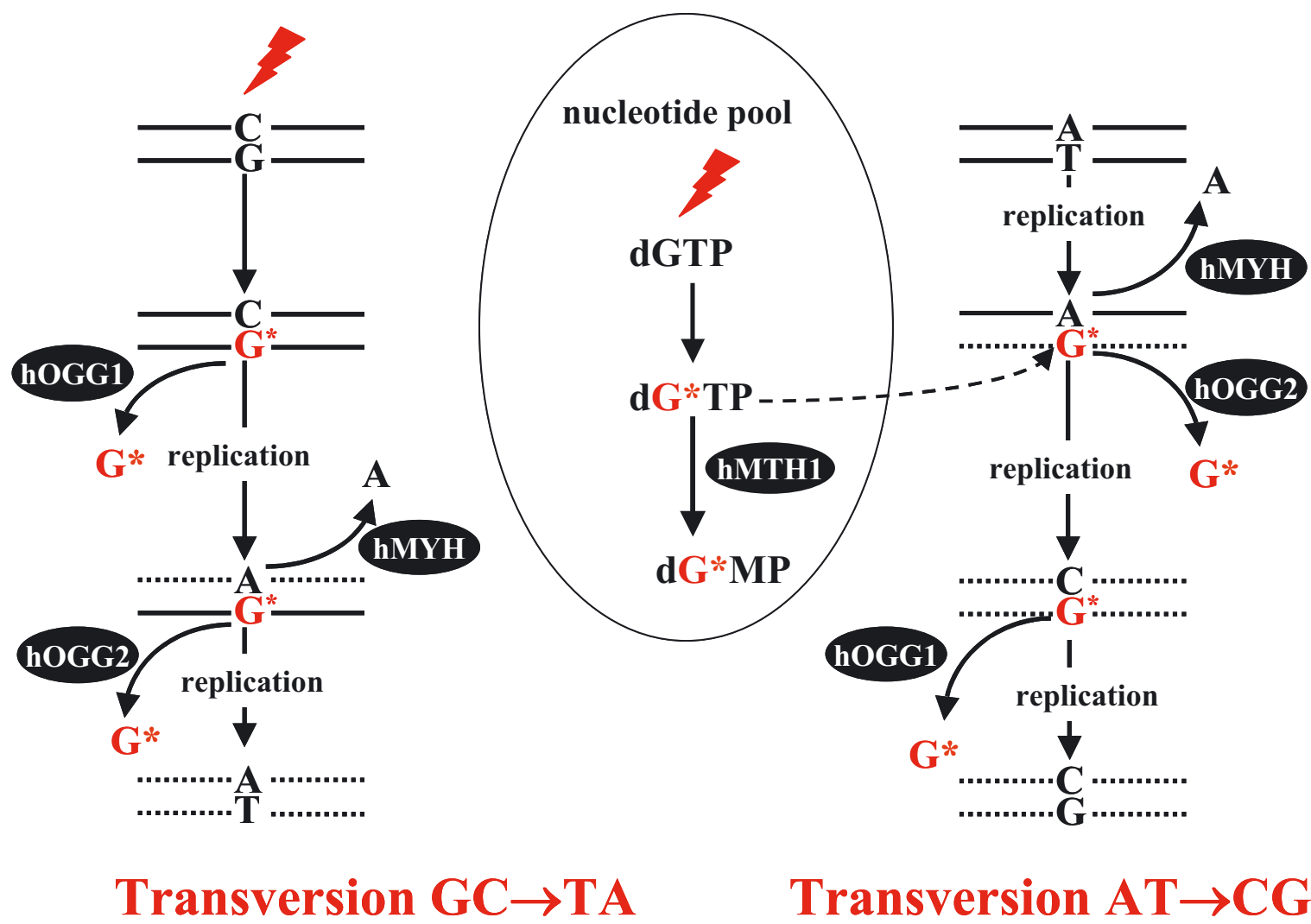

Figure 1. Prevention of transversion mutations by mammalian GO system (adapted from scheme proposed for E. coli by Michaels and Miller, 1992).

8-OxoG is formed in DNA both by direct guanine oxidation and by 8-oxodGTP incorporation from nucleotide pool. 8-OxodGTP is incorporated mainly opposite A, and thus, if unrepaired may lead to AT $\rightarrow$ CG transversion. When 8-oxoG is present in DNA it may pair with A upon replication, which leads to GC $\rightarrow$ TA transversions. hMTH1 pyrophosphohydrolase, and hOGG1, hOGG2 and hMYH glycosylases act together to prevent these mutations. E. coli cells lack hOGG2 protein, 8-oxodGTP is hydrolyzed by MutT protein, 8-oxoG is excised from pair with C by MutM glycosylase, and A is excised from pair with 8-oxoG by MutY glycosylase. $\mathrm{G}^{*}$, 8-oxoG.

mutT E. coli strain (Kamath \& Yanofsky, 1993; Bullions et al., 1994; Mejean et al., 1994). Furthermore, human, rat and mouse MutT homologue-1 (MTH1) genes have been identified, cloned and shown to suppress the increased occurrence of AT $\rightarrow$ CG transversions in E. coli mutT cells (Mo et al., 1992; Sakumi et al., 1993; Furuichi et al., 1994; Cai et al., 1995; Kakuma et al., 1995). Despite the functional homology, human MTH1 and E. coli MutT share only 30 residues $(23 \%), 14$ of which are contained in the conserved 23-residue module, while the other 16 residues are scattered throughout the whole molecules (Shimokawa et al., 2000).

The MutT protein family appeared to contain also proteins active in many other reactions, distinct from the MutT-like activity, including hydrolysis of nucleoside-5'-di- and triphosphates, dinucleoside and diphosphoinositol polyphosphates, nucleotide sugars and alcohols, dinucleotide coenzymes and RNA caps (Bessman et al., 1996; McLennan, 2006). In all the cases where the enzymatic function was known these proteins appeared to be pyrophosphohydrolases that acted upon a nucleoside diphosphate linked to some other moiety, $\mathbf{X}$, hence the name "Nudix" hydrolases was proposed for this family, with the term "MutT signature sequence" changed to "Nudix box". MutT and its functional homologues constitute a subfamily of Nudix hydrolases, where $X=$ phosphate group. It has been proposed that Nudix hydrolases are "housecleaning" enzymes which control the level of cellular metabolism by-products, metabolic intermediates and signaling compounds, whereas the specific role of MutT proteins is to "sanitize" the dNTP pool (Bessman et al., 1996).

The importance of nucleotide pool sanitization is further highlighted by the observation that dUTPase, enzyme responsible for elimination of another damaged dNTP, dUTP, is essential for survival of E. coli (el-Hajj et al., 1988), S. cerevisiae (Gadsden et al., 1993; Guillet et al., 2006) and C. elegans (Dengg et al., 2006). Interestingly, it was shown recently that abrogation of the S-phase checkpoint gene clk-2 rescued 







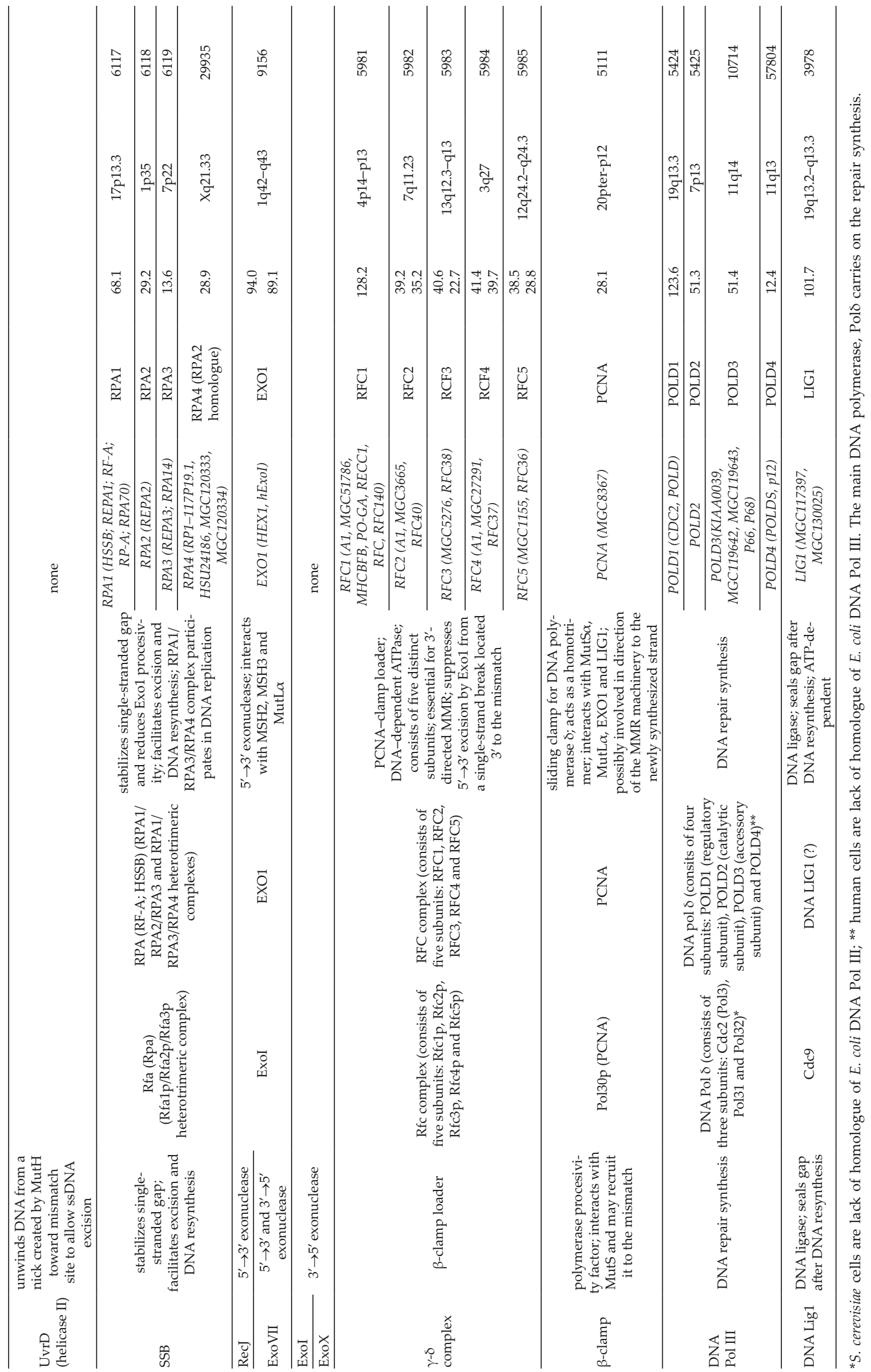


lethality and developmental defects, and eliminated cell cycle arrest and apoptosis induced by dUTPasedepletion in C. elegans. Therefore, it appears that dUMP misincorporation to DNA leads to checkpoint activation after processing by uracil-DNA glycosylase, and abrogation of the CLK-2 checkpoint leads to tolerance of DNA-repair intermediates (Dengg et al., 2006). Furthermore, methylated nucleotides, such as 1-medATP, may be repaired by E. coli oxidative demethylase AlkB (Koivisto et al., 2003); for a review of AlkB protein see Nieminuszczy \& Grzesiuk (this issue).

\section{PATHWAY OF 8-oxodGTP ELIMINATION IN MAMMALIAN CELLS - MTH1, MTH2 AND NUDT5 PROTEINS}

To counteract 8-oxodGTP incorporation to DNA, mammalian cells have an elaborate system of several enzymatic activities which convert this potentially mutagenic modified dNTP to its nucleoside, 8-oxodGuo (see Fig. 2). The 8-oxodGTP dephosphorylation pathways of E. coli and mammalian cells show some differences. In mammalian cells, like in E. coli, the whole process is initiated by 8-oxodGTP dephosphorylation to 8-oxodGMP by MTH1 protein, or to 8-oxodGDP probably by an unspecific nucleo- side triphosphatase (Mo et al., 1992). In contrast to $E$. coli MutT, MTH1 is unable to hydrolyze 8-oxodGDP and its 8-oxodGTPase activity is strongly inhibited by this oxidized dNDP, and also by 2-oxodADP (Bialkowski \& Kasprzak, 1998; Fujikawa et al., 1999). 8OxodGDP and 2-oxodADP may be phosphorylated back to 8-oxodGTP and 2-oxodATP, respectively, by nonspecific NDPK (Hayakawa et al., 1995; Kamiya \& Kasai, 1999). Importantly, 8-oxodGTP can be generated only by direct oxidation of dGTP or by phosphorylation of 8-oxodGDP, and it does not come from the ribonucleotide pool, since ribonucleotide reductase, normally catalyzing the reduction of NDPs to dNDPs, cannot convert 8-oxoGDP to 8-oxodGDP (Hayakawa et al., 1995).

To counteract the MTH1 inhibition by 8-oxodGDP, and to eliminate this potential 8-oxodGTP source, mammalian cells possess an enzymatic activity which hydrolyses 8-oxodGDP to 8-oxodGMP, namely the NUDT5 protein. NUDT5, originally discovered as ADP-sugar pyrophosphatase (Canales et al., 1995; Kim et al., 1998; Gasmi et al., 1999; Yang et al., 2000; Ribeiro et al., 2001), dephosphorylates 8-oxodGDP with high specificity, i.e. its $K_{\mathrm{m}}$ for this substrate equals $0.77 \mu \mathrm{M}$ (Ishibashi et al., 2003). Taking into account that the $K_{\mathrm{m}}$ of hMTH1 protein for 8-oxodGTP is almost 20 times higher (i.e. it is in the range of 12.5-17.3 $\mu \mathrm{M}$ (Mo et al., 1992; Fujikawa

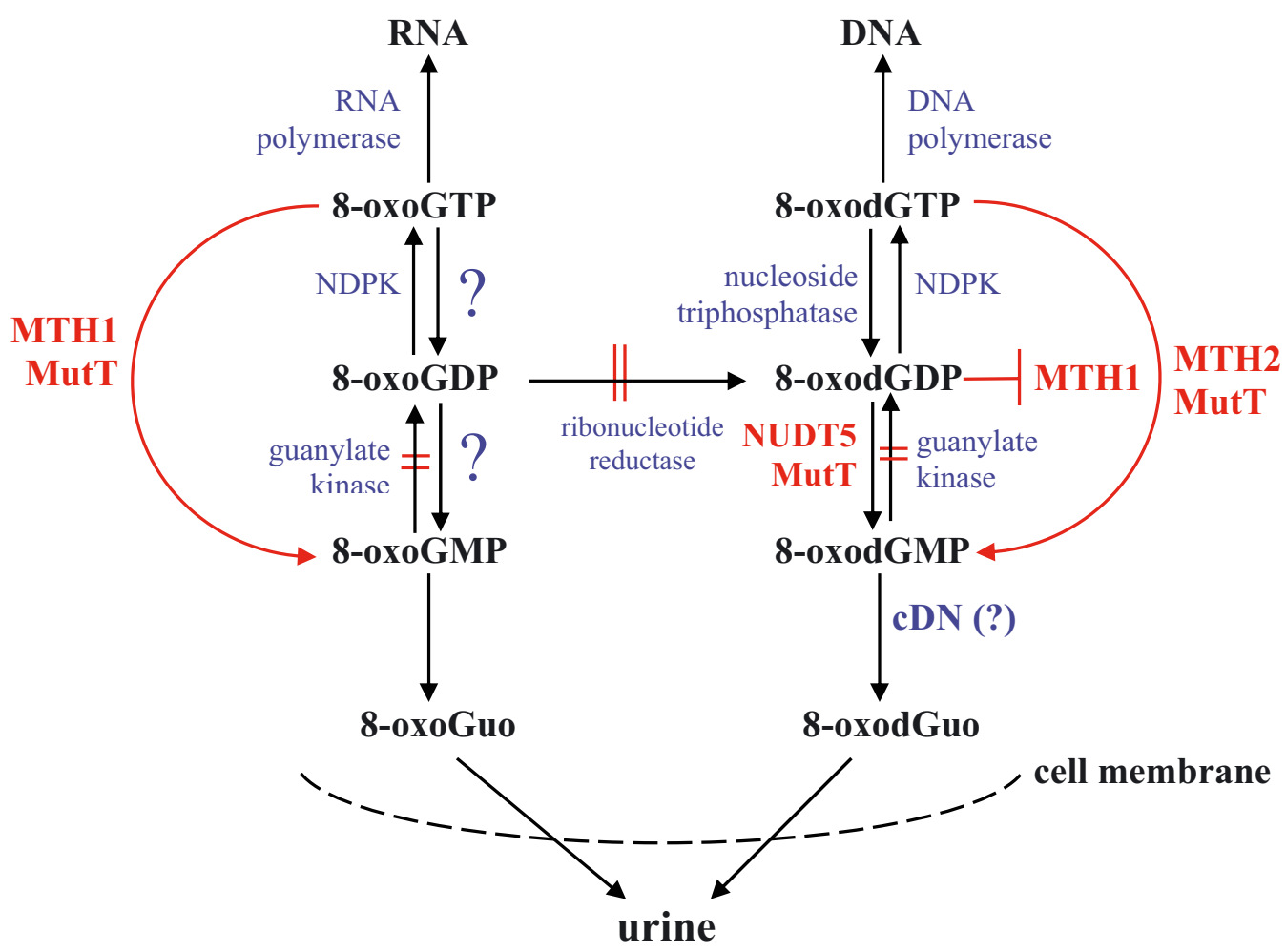

Figure 2. Pathways of interconversion of 8-oxo(d)G-containing nucleotides in E. coli and mammalian cells (based on Hayakawa et al., 1999; Ishibashi et al., 2003; 2005).

Double bars represent a block of reaction. 
et al., 1999), it can be concluded that NUDT5 may play a more important role than the MTH1 protein in prevention of 8-oxodGTP-induced mutations. Additionally, NUDT5 also prevents transcription errors by efficient 8-oxoGDP hydrolysis (Ishibashi et al., 2003). Importantly, the dephosphorylation of 8-oxodGTP or 8-oxodGDP to 8-oxodGMP by MTH1 or NUDT5, respectively, is irreversible, since guanylate kinase, normally phosphorylating dGMP to dGDP, is inactive on 8-oxodGMP (Hayakawa et al., 1995; Kim et al., 2006). Finally, 8-oxodGMP is dephosphorylated to 8-oxodGuo, probably by cytoplasmic $\quad 5^{\prime}\left(3^{\prime}\right)$-deoxyribonucleotidase $(\mathrm{cDN})$ (Hayakawa et al., 1995). This proposed pathway of 8-oxodGTP dephosphorylation is further supported by the observation that both hMTH1 expression and nucleotide pool size were shown to significantly influence the extracellular 8-oxodGuo level (Haghdoost et al., 2005; 2006). Furthermore, 8-oxodGuo is excreted to urine without further metabolism, since enzymes of purine nucleotide metabolism, which convert dGuo to uric acid, such as purine nucleoside phosphorylase (catalyzing phosphorolysis of the dGuo N-glycosidic bond with formation of guanine and deoxyribose-1-phosphate) and guanase (catalyzing deamination of guanine to xanthine) are not active on 8-oxodGuo and 8-oxoGuo, respectively (Bialkowski \& Olinski, 1997). Urinary 8-oxodGuo has been proposed to be a biomarker of oxidative stress (Shigenaga et al., 1989).

Although hMTH1 is functionally and structurally (Mishima et al., 2004) related to its E. coli counterpart, it differs from MutT in its lower substrate specificity for 8-oxodGTP, with the $K_{\mathrm{m}}$ 26-216 times higher than that of the MutT protein (Mo et al., 1992; Fujikawa et al., 1999; Kamiya et al., 2004). Interestingly, hMTH1 has been shown to have a broader substrate specificity than MutT, and it hydrolyses oxidized forms of dATP, 8-oxodATP and 2-oxodATP (Fujikawa et al., 1999), and also 8-chlorodGTP-formed by $\mathrm{HOCl}$ modification (Fujikawa et al., 2002).

Human MutT homologue (hMTH1) gene spans $9 \mathrm{~kb}$, is localized on chromosome 7p22 (Furuichi et al., 1994), and consists of five major exons, with exon 1 consisting of two segments (1a and $1 b$ ), exon 2 consisting of three segments $(2 \mathrm{a}, 2 \mathrm{~b}$ and $2 \mathrm{c}$ ), and exons 3, 4 and 5 without segmentation. Alternative splicing results in formation of seven types of transcripts $(1,2 \mathrm{~A}, 2 \mathrm{~B}, 3 \mathrm{~A}, 3 \mathrm{~B}, 4 \mathrm{~A}$ and $4 \mathrm{~B})$, with type 1 mRNA transcript predominating in most or all human cells and tissues (Oda et al., 1997). All transcripts direct formation of a 156-amino-acid (18-kDa) hMTH1 protein isoform (termed p18) from the same AUG4 located at the beginning of exon 3. Additionally, B type mRNAs (2B, 3B and 4B) have three additional upstream AUGs (AUG1, AUG2 and AUG3) localized in-frame with AUG4. AUG1 is followed by a termination codon, so functional products are produced only from AUG2, AUG3 and AUG4. Therefore, B-type mRNAs produce additionally a 171-amino-acid (p21) and a 179-amino-acid (p22) polypeptide from AUG3 and AUG2, respectively. Western blot analysis of Jurkat and HeLa cells crude extracts revealed the existence of all three isoforms of MTH1 protein (i.e. p18, p21 and p22), with the p18 isoform constituting $90 \%$. Additionally, a single nucleotide polymorphism (SNP) is present at the $5^{\prime}$ splice site $(\mathrm{GT} \rightarrow \mathrm{G} \underline{\mathrm{C}})$ of exon 2c segment, which alters the splicing pattern of exon 2c. This polymorphism destroys the termination codon after AUG1, which generates an extended open reading frame coding for a 197-amino-acid polypeptide (p26) (Oda et al., 1997). The frequency of the $C$ allele was estimated at about 7-9\% in Japanese population (Kohno et al., 2006). Computer modeling revealed that p18 and p26 proteins contain a mitochondrial targeting sequence, and the additional $\mathrm{N}$-terminal 18-aminoacid fragment of the p26 isoform constitutes a better mitochondria-targeting signal than that found in p18 isoform. All four hMTH1 isoforms were shown to have enzymatic activity (Sakai et al., 2006). One more polymorphism was discovered in exon 4 in codon 83 of the p18 hMTH1 protein coding sequence, where GTG encoding valine is changed to ATG encoding methionine (Wu et al., 1995). The Met83 variant was shown to be more thermolabile, more hydrophobic, have a higher $\alpha$-helix content and lower catalytic activity than Val83 (Yakushiji et al., 1997). The frequency of this type of polymorphic alteration in the $h M T H 1$ allele was estimated at about $9 \%$ in the Japanese population. There is a tight linkage between the two hMTH1 polymorphic sites, Met83 and GC at exon 2c, or Val83 and GT at exon 2c, which results in the synthesis of Met83-hMTH1 (p26), but not Val83-hMTH1 (p26) (Oda et al., 1999). Other polymorphisms reported for $h M T H 1$ are as follows: T to $C$ at codon 45 in exon 3, with $C$ allele frequency $2.33 \%$, silent $\mathrm{C}$ to $\mathrm{T}$ polymorphism at codon 119 in exon 5, with $\mathrm{T}$ allele frequency $2.03 \%$, C to $\mathrm{T}$ polymorphism in intron 3, and G to A polymorphism at position 92, resulting in the Arg31Gln change (Wu et al., 1995; Sieber et al., 2003; Jiang et al., 2005).

hMTH1 mRNA is abundant in human thymus, testis and embryonic tissues (Oda et al., 1997). In mice, the amounts of MTH1 mRNA found in various organs were as follows: embryonic cells $>>$ thymus, liver $>$ large intestine $>$ testis $>$ kidney, spleen > stomach, lung, heart > brain (Kakuma et al., 1995; Igarashi et al., 1997). In human cells hMTH1 protein is localized mainly in the cytoplasm and nucleus, with $5-10 \%$ present in mitochondria (mainly in the mitochondrial matrix) (Kang et al., 1995; Yoshimura et al., 2003). 


\section{ROLE OF hMTH1 IN HUMAN DISEASE}

It has been proposed that an early step in carcinogenesis is elevation of the rate of spontaneous mutations, i.e. development of a mutator phenotype (Loeb, 2001; Beckman \& Loeb, 2006; Venkatesan et al., 2006). Since MutT-deficient E. coli cells show a clear mutator phenotype, the hMTH1 gene was suspected to be one of the genes whose deficiency would be involved in cancer progression. Consistently with this assumption, MTH1-knockout mice showed a higher incidence of lung, liver and stomach cancer (Tsuzuki et al., 2001a; 2001b). However, no mutations or polymorphisms in the hMTH1 gene were found to be correlated with hereditary nonpolyposis colorectal cancer (HNPCC) (Wu et al., 1995), acute childhood leukemia (Lin et al., 1998b), hepatocellular carcinoma, lung cancer (Oda et al., 1999), ovarian cancer (Takama et al., 2000), familial adenomatous polyposis (FAP), sporadic colorectal cancer (Sieber et al., 2003; Kim et al., 2004), nor with Parkinson's disease (Satoh \& Kuroda, 2000). Similar$1 y$, no such correlation was found in the rat 2-amino-1-methyl-6-phenylimidazo[4,5- $b]$ pyridine (PhIP)induced mammary carcinomas, which showed an elevated level of AT $\rightarrow$ CG transversions (Okochi et al., 2002a; 2002b). On the other hand, the Val83Met polymorphism is suggested to be involved in the development of type 1 diabetes mellitus in female Japanese (Miyako et al., 2004), and together with the $\mathrm{T} / \mathrm{C}$ polymorphism in exon 2, with the risk of small cell lung cancer (SCLC), but not with non-small cell lung cancer (NSCLC) (Kohno et al., 2006). Furthermore, the Val83Met polymorphism was shown to be more frequent in gastric cancer patients, and the Met83 variant correlated with somatic mutations in TP53 tumor suppressor gene (Kimura et al., 2004).

Surprisingly, in various types of tumors and disease states, and in rodent models of human diseases, MTH1 overexpression was found to be more common than its mutation. Thus, MTH1 mRNA was shown to be overexpressed in renal cell carcinoma (Okamoto et al., 1996), lung cancer cells and NSCLC tissues (Hibi et al., 1998; Kennedy et al., 1998), hepatocellular carcinoma (Zhou et al., 2005), breast cancer (Wani et al., 1998), PhIP-induced rat mammary carcinomas (Okochi et al., 2002a; 2002b), MTH1 protein level was shown to be increased in brain tumors (Iida et al., 2001), NSCLC (Kennedy et al., 2003), colorectal cancer (Koketsu et al., 2004), lung epithelial cells of patients with idiopathic interstitial pneumonias (Kuwano et al., 2003), mouse heart after myocardial infarction (Tsutsui et al., 2001), and hMTH1 activity was shown to be increased in NSCLC (Speina et al., 2005) in comparison with non affected tissues or cells. Furthermore, hMTH1 overexpression was also observed in regions involved in oxidative stress-in- duced damage in brains of patients with Parkinson's (Shimura-Miura et al., 1999) and Alzheimer's disease (Furuta et al., 2001), in nuclei of motor neurons of patients with amyotrophic lateral sclerosis (Kikuchi et al., 2002), and also was shown to protect mouse neurons from oxidative stress damage in a 1-methyl4-phenyl-1,2,3,6-tetrahydropyridine induced Parkinson's disease model (Yamaguchi et al., 2006), and in kainate-induced excitotoxicity (Kajitani et al., 2006). Furthermore, MTH1 was also shown to suppress $\mathrm{H}_{2} \mathrm{O}_{2}$-induced cell death in mouse embryo fibroblasts (Yoshimura et al., 2003). Consistently with the above results, MTH1 overexpression was observed under oxidative stress induced by $\mathrm{H}_{2} \mathrm{O}_{2}$ in cultured glioma cells (Iida et al., 2004), human skin fibroblasts and Jurkat cells (Meyer et al., 2000), and in cells exposed to various toxic agents, such as in the case of human lung tissues of tobacco-smoking NSCLC patients (Arczewska et al., in preparation), human fibroblasts exposed to ionizing radiation (Haghdoost et al., 2006), in livers of rats treated with carbon tetrachloride (Takahashi et al., 1998), rat lung epithelial cells treated with urban particulate matter (Choi et al., 2004), human lung epithelial cells treated with crocidolite asbestos (Kim et al., 2001), and also in tissues exposed to a high level of toxic metabolites excreted from the organism, such as the rat kidney inner cortex (Kasprzak et al., 2001) and human colorectal cancers located in the distal part of the colon (Koketsu et al., 2004). Furthermore, hMTH1 overexpression was observed under increased oxygen consumption, i.e. in leukocytes of healthy subjects after exercises (Sato et al., 2003). All the above observations have led to the conclusion that hMTH1 overexpression is a molecular marker of oxidative stress, especially in cancer cells (Kennedy et al., 1998), and was even proposed to be a marker for diagnosis of patients with non-small cell lung cancer (Chong et al., 2006). In fact, hMTH1 overexpression has proved to be a reliable marker of oxidative stress in cancer and other diseases, since a high level of its expression in peripheral lymphocytes was shown to be associated with increased risk of prostate cancer (Liu et al., 2003), and its overexpression was observed in lymphocytes of uremic patients (Tarng et al., 2004).

The role of MTH1 in oxidative-damage prevention is further highlighted by the observation that hMTH1 mRNA level is inversely correlated with 8-oxoG DNA level in human lung cancer cell lines (Kennedy et al., 1998) and in leukocytes of healthy subjects after exercise (Sato et al., 2003), a higher hMTH1 mRNA level coincides with lower 8-oxoG DNA levels in human lung epithelial cells treated with crocidolite asbestos (Kim et al., 2001), a higher MTH1 activity coincides with lower 8-oxoG DNA levels in fetal compared to maternal mouse organs (Bialkowski et al., 1999b), a higher hMTH1 
protein level coincides with higher 8-oxodGuo levels in the cytoplasm and mitochondria of substantia nigra neurons of patients with Parkinson's disease (Shimura-Miura et al., 1999) and the hMTH1 protein level is positively correlated with extracellular 8-oxodGuo level in cell cultures (Haghdoost et al., 2006). Furthermore, treatment of rats with cadmium (II) $(\mathrm{Cd}(\mathrm{II}))$, which inhibits the activity of the MutT and MTH1 proteins (Porter et al., 1997; Bialkowski \& Kasprzak, 1998), resulted in a decrease of MTH1 activity concurrently with an increase of 8-oxoG level in DNA of the testis, the target organ of $\mathrm{Cd}(\mathrm{II})$-induced mutagenesis (Bialkowski et al., 1999a).

Interestingly, although MTH1 expression was found to be increased in replicating cells (Wani \& D'Ambrosio, 1995), stimulated by phytohemagglutinin and interleukin-2 (Oda et al., 1997), and higher in tissues with highly proliferating cells, such as thymus and testis, than in tissues with non-proliferating cells, such as brain (Kakuma et al., 1995; Igarashi et al., 1997; Oda et al., 1997), Bialkowski and Kasprzak (2004) have shown that MTH1 protein activity is not regulated by the cell proliferation rate. Furthermore, the MTH1 protein activity does not depend on the cell cycle stage, and is not changed under serum starvation of cultured cells, but decreases with increasing cell population density (Bialkowski \& Kasprzak, 2000). Therefore, although MTH1 overexpression under oxidative stress and in cancer cells is a well-recognized feature, the actual mechanisms that are involved in this phenomenon remain to be elucidated.

\section{PREVENTION OF 8-oxoG-INDUCED MUTATIONS BY GO SYSTEM - COOPERATION OF THE hMTH1 PROTEIN AND BER PATHWAY}

8-OxoG may be formed in DNA by G oxidation or by 8-oxodGTP incorporation opposite A or C (see Fig. 2). In E. coli 8-oxoG paired with C is removed by MutM protein, but, if unrepaired it may pair with A upon replication and thus GC $\rightarrow$ TA transversions occur. On the other hand, A is removed from the 8 -oxoG $\bullet A$ pair by MutY protein, which prevents $\mathrm{GC} \rightarrow \mathrm{TA}$ transversions. Paradoxically, if 8-oxoG comes from 8-oxodGTP incorporated opposite A, then removal of A by MutY would induce $\mathrm{AT} \rightarrow \mathrm{CG}$ transversions, since 8-oxoG may pair with $C$ upon replication. Therefore, the MutT protein hydrolyzing 8-oxodGTP is crucial in prevention of $\mathrm{AT} \rightarrow \mathrm{CG}$ transversions. Altogether, MutM, MutY and MutT were proposed to cooperate in prevention of 8-oxoG (GO)-induced mutations, and this prevention system was termed GO (Michaels \& Miller, 1992). Consistently, GC $\rightarrow$ TA transitions are greatly increased in an E. coli mutMmutY double mutant, but in the triple mutant mutMmutYmutT their frequency is not further increased. This phenomenon may be explained by 8-oxoG removal by Nei glycosylase (for a review see Krwawicz et al., this issue) or other DNA repair systems, such as MMR (see below) or NER (Czeczot et al., 1991; Bregeon et al., 2003). On the other hand, mutMmutYmutT and mutYmutT show a lower level of $\mathrm{AT} \rightarrow \mathrm{CG}$ transversions than mutMmutT and mutT, which confirms that MutY activity in fact enhances 8-oxodGTP-induced mutagenesis (Fowler et al., 2003).

Mammalian cells possess three main $\mathrm{N}$-glycosylases that prevent 8-oxoG-induced mutations: OGG1, which preferentially removes 8-oxoG from pairs with $\mathrm{C}$ or $\mathrm{T}$, OGG2, which removes 8-oxoG paired with $\mathrm{G}$ or $\mathrm{A}$, and $\mathrm{MYH}$, which removes $\mathrm{A}$ from the pair with 8-oxoG. Mammalian OGG2 has been proposed to remove mainly 8-oxoG incorporated from the cellular nucleotide pool (for a review see (Nakabeppu et al., 2006)). Similarly like in E. coli cells, OGG1 and MYH are key players in GC $\rightarrow$ TA

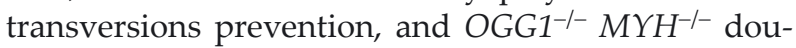
ble knockout mice show an increased level of $\mathrm{G} \rightarrow$ $\mathrm{T}$ transversions together with a very high incidence of tumors (Xie et al., 2004). Surprisingly, MTH1 disruption appeared to suppress lung tumorigenesis in OGG1-knockout mice, which was attributed to the increased cell death of damaged tumor progenitor cells upon extensive 8-oxoG incorporation in DNA and RNA (Sakumi et al., 2003).

\section{MISMATCH REPAIR (MMR)}

Mismatch repair (MMR) is the major postreplicative DNA repair system, which increases replication fidelity up to 1000-fold (Modrich \& Lahue, 1996; Schofield \& Hsieh, 2003). MMR removes primary replication errors that escaped DNA polymerase proofreading, such as base-base mismatches and small insertion/deletion loops (IDLs), which are most easily formed in long repetitive sequences, i.e. in microsatellites. Thus, defects in MMR induce the mutator phenotype characterized by changes in the microsatellites length, termed microsatellite instability (MSI). MSI is an established biomarker for MMR dysfunction in tumor cells (Umar et al., 2004).

Additionally, MMR repairs also modified bases, such as 8-oxoG (Ni et al., 1999; Mazurek et al., 2002; Macpherson et al., 2005), 2-oxoadenine (Barone et al., 2007), carcinogen adducts ( $\mathrm{Li}$ et al., 1996), and UV-photoproducts (Feng et al., 1991; Mu et al., 1997; Wang et al., 1999). MMR processes also natural bases paired with template $O^{6}$-methylguanine, $O^{4}$-methylthymine, (Duckett et al., 1996; Rasmussen \& Samson, 1996), 1, $N^{2}$-propanoguanine, malondialdehyde-guanine $\left(M_{1} G\right)$ (Johnson et al., 1999) and cisplatin ad- 
ducts (Duckett et al., 1996; Mello et al., 1996; Yamada et al., 1997). This induces MMR-mediated cytoxicity and MMR-defective cells are resistant to methylating agents and cisplatin.

Finally, MMR participates in affinity maturation of antibodies, regulation of the mitotic and meiotic recombination, DNA-damage signaling, apoptosis (reviewed in: Harfe \& Jinks-Robertson, 2000; Schofield \& Hsieh, 2003; Jiricny, 2006), and transcription-coupled repair (TCR) (see, for example, Lee et al., 2004). Furthermore, paradoxically, rearrangements resulting in expansions of tandem trinucleotide repeats, observed in disorders such as Huntington's disease, fragile $X$ syndrome and myotonic dystrophy, have been shown to depend on functional MMR proteins in mice (Manley et al., 1999; Kovtun \& McMurray, 2001; van den Broek et al., 2002; Savouret et al., 2003; Gomes-Pereira et al., 2004), and consistently MutS $\beta$ was shown to bind hairpin loops formed by such trinucleotide repeats (Owen et al., 2005). Thus, in this case functional MMR rather induces genome destabilization, which may promote disease development.

\section{Methyl-directed MMR in E. coli}

Key players in the E. coli MMR system, MutS, MutL, MutH and UvrD were identified in studies of mutator strains (Cox et al., 1972; Wagner \& Meselson, 1976), and the whole system was reconstituted in vitro (Lahue et al., 1989). MMR preferentially repairs the newly synthesized strand, and in E. coli strand discrimination is based on the fact that adenine is methylated in GATC sequences by Dam methyltransferase about 2 min after DNA synthesis, therefore the newly synthesized strand is transiently unmethylated (Lyons \& Schendel, 1984). Consistently with its role in MMR, dam E. coli cells are weak mutators (Glickman, 1979).

Initially, MutS protein dimer (or tetramer) recognizes and binds IDLs containing up to about four unpaired bases (Parker \& Marinus, 1992), and also seven of eight possible mismatches (Su \& Modrich, 1986; Su et al., 1988). MutS binding affinities and mismatch repair efficiencies vary with the composition of the mismatch and local sequence context, with $\mathrm{G} \bullet \mathrm{T}$ and $\mathrm{C} \bullet \mathrm{A}$ mismatches being preferentially repaired in most of the tested systems (Kramer et al., 1984; Dohet et al., 1985; Jones et al., 1987; Brown et al., 2001). Consistently, defects in MMR genes induce mainly GC $\rightarrow$ AT and AT $\rightarrow$ GC transitions, and frameshift mutations (Lahue et al., 1989). The C•C mismatch is almost not recognized by MutS and it was postulated to be repaired by an MMR-independent pathway (Nakahara et al., 2000). Further, mismatch-bound MutS recruits MutL dimer in an ATP-dependent manner (Grilley et al., 1989). The
MutL protein is an ATPase and is thought to be a "molecular matchmaker" which mediates the interaction between MutS and MutH (Modrich, 1991). Thus formed, the ternary complex of MutS(ATP)MutL-mismatch activates monomeric MutH endonuclease which incises an unmethylated GATC sequence at a site $5^{\prime}$ or $3^{\prime}$ to the mismatch, located even $1000 \mathrm{bp}$ from the mismatch (Welsh et al., 1987; Bruni et al., 1988). The resulting nick serves as the point of entry for MutL-activated UvrD helicase, which unwinds DNA double helix from the nick to about 100 nucleotides past the mismatch, and single-stranded DNA binding (SSB) protein, which stabilizes the single-stranded gap (Lahue et al., 1989). After unwinding the ssDNA flap is degraded in the $5^{\prime} \rightarrow 3^{\prime}$ direction by ExoVII or RecJ exonuclease, if the incision occurred $5^{\prime}$ to the mismatch, or in the $3^{\prime} \rightarrow$ 5 ' direction by ExoI, ExoVII or Exo $\mathrm{X}$ exonuclease, if the incision occurred 3' to the mismatch (Cooper et al., 1993; Grilley et al., 1993; Burdett et al., 2001). Finally, the SSB-stabilized single-stranded gap is filled in by DNA polymerase III holoenzyme and DNA ends are sealed by LigI. Importantly, $\beta$ clamp, which is a polymerase processivity factor, and $\gamma$ complex, which loads $\beta$ clamp onto the DNA helix are required for MMR in vitro (Lahue et al., 1989), and $\beta$ clamp was shown to interact with MutS (Lopez de Saro \& O'Donnell, 2001).

\section{MMR in eukaryotes}

In eukaryotes several homologs of MutS and MutL have been identified, including six $\underline{m} u t \underline{S}$ homologues (MSH1-MSH6) and four mutL homologues (MLH1-MLH3, and PMS1) found in yeast (Kramer et al., 1989; Reenan \& Kolodner, 1992a; 1992b; New et al., 1993; Prolla et al., 1994; Ross-Macdonald \& Roeder, 1994; Hollingsworth et al., 1995; Marsischky et al., 1996), and five mutS (MSH2-MSH6) and four mutL (MLH1, MLH3, PMS1, and PMS2) homologues found in mammals (Hughes \& Jiricny, 1992; Fishel et al., 1993; Leach et al., 1993; Bronner et al., 1994; Nicolaides et al., 1994; Papadopoulos et al., 1994; Liu et al., 1994; Varlet et al., 1994; Horii et al., 1994; Drummond et al., 1995; Li \& Modrich, 1995; Palombo et al., 1995; Baker et al., 1995; Acharya et al., 1996; Watanabe et al., 1996; Paquis-Flucklinger et al., 1997; Her \& Doggett, 1998; Winand et al., 1998; Lipkin et al., 2000).

Although MutS and MutL proteins are evolutionarily conserved, the MutH endonuclease is restricted only to Gram-negative bacteria (Jiricny, 2006). Thus, in eukaryotic cells the signals that direct MMR to the newly synthesized strand remain uncertain. Initially it has been proposed that strands are discriminated on the basis of cytosine methylation, analogously to the role of adenine methylation in $E$. coli cells, but this hypothesis has not been veri- 
fied (Drummond \& Bellacosa, 2001; Petranovic et al., 2000). More plausible hypotheses suggest that natural single-strand breaks, occurring as replication intermediates, the replication complex, especially proliferating cell nuclear antigen (PCNA), or proteins segregating with individual strands after replication may be involved. This was supported by the observation that mutH E. coli strains are able to carry out MutHindependent MMR, both in vivo and in vitro, from a single-strand break located at the vicinity of the mismatch (Lahue et al., 1989; Kramer et al., 1984; Bruni et al., 1988). The same was observed in human in vitro MMR assays (Holmes et al., 1990; Thomas et al., 1991; Iams et al., 2002). Furthermore, similarly as observed in E. coli, the eukaryotic $\beta$ clamp counterpart - PCNA - interacts with yeast and human MutS and MutL homologues (Umar et al., 1996; Clark et al., 2000; Flores-Rozas et al., 2000; Kleczkowska et al., 2001), and mutations in PCNA that abolish interaction with MSH3 and MSH6 confer partial mutator phenotype in vivo (Johnson et al., 1996; Chen et al., 1999; Clark et al., 2000; Flores-Rozas et al., 2000; Lau et al., 2002; Lau \& Kolodner, 2003). Thus, PCNA is implicated not only in gap filling repair synthesis, but also in early stages of MMR (Umar et al., 1996; $\mathrm{Gu}$ et al., 1998). Moreover, PCNA and eukaryotic clamp loader replication factor $\underline{C}$ (RFC) were shown to be essential for bi-directional excision during MMR (Dzantiev et al., 2004). Human MSH2 and MSH3 interact also with MMR exonuclease - Exo1 (Schmutte et al., 1998; 2001; Rasmussen et al., 2000).

Eukaryotic MMR proteins function as heterodimers. MSH2-MSH6 form a heterodimer, termed MutS $\alpha$, which recognizes all eight single base mismatches, including $\mathrm{C} \cdot \mathrm{C}$ mismatch, and small IDLs, up to about 10 unpaired nucleotides, whereas the MSH2-MSH3 heterodimer (MutS $\beta$ ) recognizes IDLs containing from 2 up to 16 nucleotides (McCulloch et al., 2003). In human cells the MutS $\alpha$ to MutS $\beta$ ratio is roughly 6:1 (Drummond et al., 1995; 1997; Palombo et al., 1995; 1996; Acharya et al., 1996; Genschel et al., 1998; Umar et al., 1998). Consistently, MSH6deficient tumor cells show mononucleotide (but not dinucleotide) instability (Kolodner et al., 1999; Verma et al., 1999), and MSH3-deficient cells do not display microsatellite instability (Inokuchi et al., 1995). Mammalian MSH4 and MSH5 also form a heterodimer, show germ cell-specific expression and are involved in meiotic recombination, but not postreplicative MMR (Ross-Macdonald \& Roeder, 1994; Bocker et al., 1999; Kneitz et al., 2000; Snowden et al., 2004). MutSa forms an ATP-dependent sliding clamp, but it is still not evident if the movement of MutS $\alpha$ on DNA is driven by ATP hydrolysis (Blackwell et al., 1998), or is ATP hydrolysis-independent (Gradia et al., 1997) (Fig. 3; for discussion of the proposed models see: Kunkel \& Erie, 2005; Iyer et al., 2006; Jiricny, 2006).
Next, MutS $\alpha$ (or MutS $\beta$ ) recruits MutL $\alpha$ ATPase (MLH1-PMS2 heterodimer; in yeast MLH1-PMS1 heterodimer) (Li \& Modrich, 1995), and MutS $\alpha-M u t L \alpha$ complexes may travel along the DNA helix, similarly to the MutS $\alpha$ sliding clamp (Blackwell et al., 2001). MutL $\alpha$ has been proposed to be important for coupling mismatch recognition with further MMR steps and consistently it interacts with Exo1 (Schmutte et al., 2001; Tran et al., 2001) and PCNA (Umar et al., 1996; Lee \& Alani, 2006). Importantly, MutL $\alpha$ deficiency leads to the mutator phenotype and MSI, as observed in sporadic colorectal or endometrial cancers with epigenetic silencing of MLH1 expression (Kane et al., 1997; Cunningham et al., 1998; Esteller et al., 1998; Herman et al., 1998; Veigl et al., 1998; Wheeler et al., 1999). Moreover, several MLH1 mutations found in hereditary non-polyposis colorectal cancer (HNPCC) patients were found to reduce interaction with Exo1 (Schmutte et al., 2001). Other mammalian MutL homologues also function in heterodimers. MLH1 and PMS1 form the MutL $\beta$ heterodimer whose function is still unknown, but PMS1knockout mice exhibit MSI at mononucleotide runs (Prolla et al., 1998), which may suggest that MutL $\beta$ is somehow involved in MMR. Moreover, MLH1 and MLH3 form the MutL $\gamma$ heterodimer which is thought to participate in the repair of base-base mismatches and single-nucleotide IDLs (Cannavo et al., 2005), and murine cells with MLH3 deficiency display the MSI phenotype (Lipkin et al., 2000). MutL $\gamma$ is also involved in meiotic recombination (Santucci-Darmanin et al., 2000; Lipkin et al., 2002; Svetlanov \& Cohen, 2004). One more protein engaged in MMR is highmobility group box 1 (HMGB1) protein, which was shown to interact with MutS $\alpha$ and is required prior to the excision step (Yuan et al., 2004).

Final steps of MMR include mismatch excision and DNA resynthesis. When a single-strand break is localized at the $5^{\prime}$ side of the mismatch, Exo1, stimulated by MutS $\alpha$ hydrolyzes DNA in the $5^{\prime} \rightarrow 3^{\prime}$ direction in an ATP-, mismatch-, and replication protein A (RPA)-dependent manner (Lin et al., 1998a; Genschel et al., 2002; Lee Bi et al., 2002). RPA plays a role similar to E. coli SSB, since it protects ssDNA from incision by nucleases (Ramilo et al., 2002). Furthermore, eukaryotic MMR is apparently helicase-independent (Bennett et al., 1997; Langland et al., 2001; Pedrazzi et al., 2001), and thus RPA binding has been proposed to play some role in DNA unwinding. Exo1 is the only eukaryotic MMR exonuclease, and Exo1-deficient mice are prone to lymphomas and exhibit MSI, as well as the mutator phenotype (Wei et al., 2003; Tran et al., 2004). The single stranded gap is stabilized by RPA. RPA reduces Exo1 processivity by binding SsDNA, and Exo1 is further inhibited by MutS $\alpha$ and MutL $\alpha$ upon reaching the mismatch. This leads to termination of excision. In consequence 
A Molecular-switch model

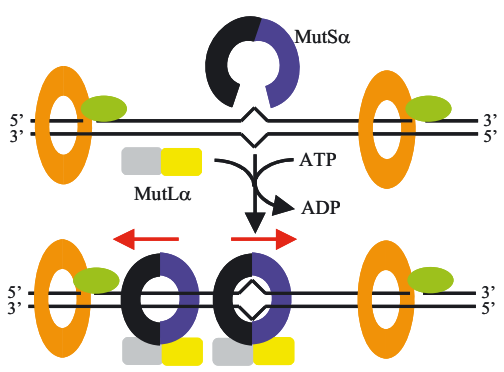

B



C DNA bending/veryfication model
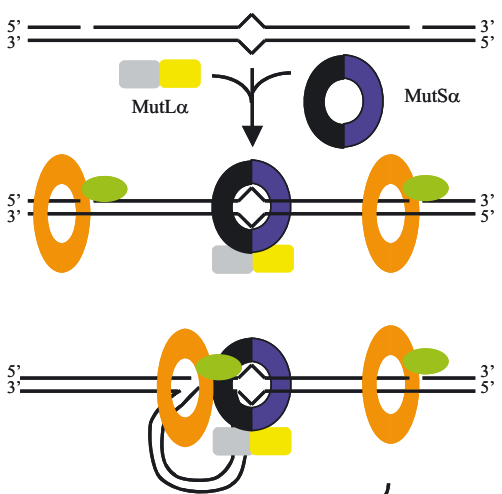

D
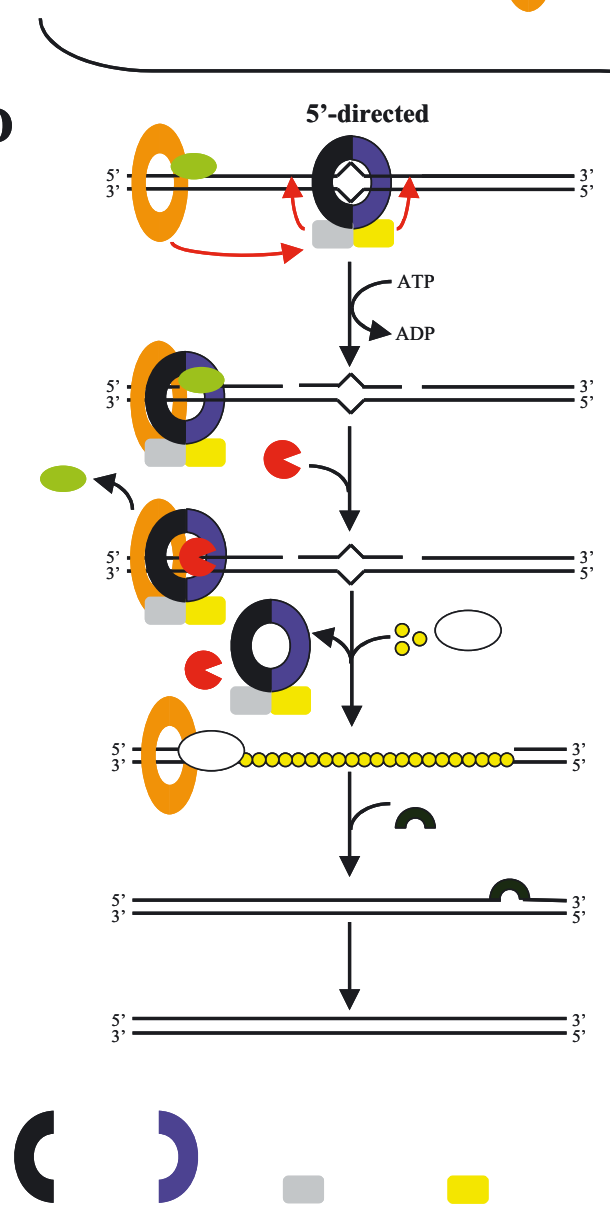

$\mathrm{MSH} 2$

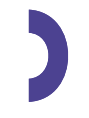

MSH6

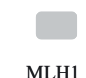

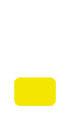

PMS2

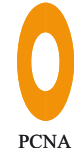

Figure 3. Models of MMR complex assembly (A, B and C) and mismatch excision (D).

(A) In the molecular-switch model (Gradia et al., 1999) MutS $\alpha$ normally exists in ADP-bound form, and upon mismatch binding ADP is exchanged to ATP, which induces conformational changes and ATP-independent diffusion of multiple MutS $\alpha$ (possibly in complex with MutL $\alpha$ ) sliding clamps along DNA helix. (B) In the active-translocation model (Blackwell et al., 1998; Martik et al., 2004), MutS $\alpha$ clamp (possibly in complex with MutL $\alpha$ ) translocates along DNA and ATP is used as energy source to drive its motion. (C) In the DNA bending/verification model (Wang \& Hays, 2003; 2004) MutS $\alpha$ remains at the mismatch and makes contact with strand break through DNA bending. MutS is able to sense the mismatch, and when bound to DNA without mismatch it hydrolyzes ATP and in consequence becomes displaced from the DNA. On the other hand, when MutS binds DNA containing mismatch, ATP is not hydrolyzed, what leads to activation of downstream MMR effectors. (D) When MutS $\alpha-$ MutL $\alpha$ complex comes into contact with PCNA and RFC bound to strand break, it triggers further MMR steps. MutS $\alpha$, PCNA and RFC activate latent MutL $\alpha$ endonuclease (Kadyrov et al., 2006), which cleaves DNA at both sides of the mismatch in ATP-dependent manner. Next, at the 5'-break (created by MutL $\alpha$ endonucleolytic cleavage or preexisting in DNA) MutS $\alpha-M u t L \alpha$ complex displaces RFC from complex with PCNA and loads Exo1, which hydrolyzes DNA in $5^{\prime} \rightarrow 3^{\prime}$ direction. The single stranded gap is stabilized by RPA. RPA reduces Exo1 processivity by binding ssDNA, and Exo1 is further inhibited by MutS $\alpha$ and MutL $\alpha$ upon reaching the mismatch. This leads to termination of excision. Finally, gap is filled by Pol $\delta$, in presence of PCNA and RPA, and ends are joined by LIG1. 
excision terminates at about 100 nucleotides beyond the mismatch (Genschel \& Modrich, 2003; Nielsen et al., 2004). However, Exo1 lacks the $3^{\prime} \rightarrow 5^{\prime}$ exonuclease activity, and a complex consisting of $\mathrm{MutS} \alpha$, MutL $\alpha$, PCNA, Exo1, and RFC is essential for MMR from a single-strand break located at the $3^{\prime}$ side of the mismatch (Dzantiev et al., 2004; Guo et al., 2004). RFC has been proposed to play a double role in $3^{\prime}$ directed excision: it loads the PCNA clamp, but also suppresses $5^{\prime} \rightarrow 3^{\prime}$ excision by Exo1 from a singlestrand break located $3^{\prime}$ to the mismatch (Dzantiev et al., 2004). It has been proposed that $3^{\prime} \rightarrow 5^{\prime}$ excision is mediated by $\operatorname{Pol} \delta$ or Pol $\varepsilon$ proofreading activity, which was supported by genetic and biochemical inhibition studies conducted in vivo in S. cerevisiae and in vitro with HeLa extracts (Tran et al., 1999; Wang \& Hays, 2002). The recent discovery that MutL $\alpha$ has an endonuclease activity, stimulated by MMR cofactors (MutS $\alpha$, MutL $\alpha$, PCNA, RFC, ATP and divalent cations) (Kadyrov et al., 2006) may explain the MMR mechanism in a situation when the single strand break is located at the $3^{\prime}$ side of the mismatch. Thus, the $5^{\prime}$ nick introduced by this endonuclease activity specifically in the discontinuous strand may serve for Exo1 degradation in substrates containing a break localized $3^{\prime}$ to the mismatch. Finally, DNA polymerase $\delta$ fills the gap, in the presence of PCNA (Gu et al., 1998) and RPA (Lin et al., 1998a; Ramilo et al., 2002), and finally DNA ligase (probably LIG1) seals the ends (Constantin et al., 2005; Zhang et al., 2005).

MMR and hereditary non-polyposis colorectal cancer (HNPCC)

Defects in MMR are implicated in hereditary non-polyposis colorectal cancer (HNPCC), also termed Lynch syndrome, and less frequently in endometrial, ovarian, gastric and some other cancer forms. Colon epithelium has the highest known proliferation rate of all cell types, and this may directly contribute to the accumulation of MMR-deficiency-induced replication errors specifically in this tissue type. Lynch syndrome accounts for about $5-8 \%$ of all colon cancer cases. About 500 different Lynch syndrome-associated MMR gene mutations have been found, and among them MLH1, MSH2, and MSH6 gene mutations constitute about 50\%, $40 \%$, and $10 \%$, respectively (for mutations found in respective genes see http: //www.insight-group. org/). Mutations in MSH6 show stronger association with endometrial than colon cancer (Wijnen et al., 1999). Mice defective in either MLH1, MSH2 or MSH6 show cancer susceptibility and develop mainly lymphomas, gastrointestinal (GI) epithelial adenomas or basal cell carcinomas, whereas $P M S 2^{-/-}$ mice develop lymphomas and sarcomas, but not GI tumors. Moreover, a few pathogenic germline muta- tions have been found in PMS2 and most of them are associated with Turcot syndrome, characterized by brain tumors, colonic polyps and colon cancer. Finally, mutations in MLH3 may also be associated with Lynch syndrome. On the other hand, although MSH3 frequently shows somatic mutations in MSIpositive tumors, and potentiates the consequences of defects in other MMR genes, MSH3-deficient mice are not cancer prone and no Lynch syndrome-associated germline mutations have been found in MSH3 (Lynch \& de la Chapelle, 1999; Peltomaki, 2005; Chao \& Lipkin, 2006).

Microsatellite instability (MSI) is found in virtually all Lynch syndrome cases (Aaltonen et al., 1994), and thus is a diagnostic feature for Lynch syndrome. However, MSI also appears in sporadic (i.e. non-Lynch syndrome) colon cancers, where hypermethylation of MLH1 promoter leads to gene silencing (Kane et al., 1997; Cunningham et al., 1998; Esteller et al., 1998; Herman et al., 1998; Veigl et al., 1998; Wheeler et al., 1999). Thus, although $12-15 \%$ of colon cancers show MSI, only $20-25 \%$ of MSI-positive colon cancers represent Lynch syndrome, which complicates diagnosis (Lynch \& de la Chapelle, 1999; Umar et al., 2004; Jass, 2006).

\section{COOPERATION BETWEEN hMTH1 PROTEIN AND MMR}

The antimutagenic role of MTH1 is less pronounced than that of the MutT protein, since while the $m u t T E$. coli mutant has a specifically increased level of spontaneous mutations by 100- to 10000-fold, their level in the Hprt locus of homozygous $\mathrm{MTH}^{-/-}$ mouse cells is increased only 2 times in comparison with the wild type $\mathrm{MTH1}^{+/+}$mouse cells (Tsuzuki et al., 2001a; 2001b). This low level of spontaneous mutations can be explained, at least partially, by the existence of MutT homologue 2 (MTH2) protein, which is active on 8-oxodGTP and may backup MTH1 function (Cai et al., 2003), and by the existence of NUDT5 protein. Importantly, both proteins, i.e. mouse MTH2 and human NUDT5 expressed in the mutT E. coli strain suppressed its mutator phenotype (Cai et al., 2003; Ishibashi et al., 2003). Furthermore, mutagenesis may be prevented by efficient removal of oxidized bases incorporated from the cellular dNTP pool by DNA repair systems, such as BER, MMR or NER. Interestingly, although the $\mathrm{MTH}^{-/-}$mice showed a higher incidence of lung, liver and stomach cancer (Tsuzuki et al., 2001a; 2001b), they did not show an increased frequency of spontaneous $r p s L^{-}$forward mutations in comparison with the wild type $M T H 1^{+++}$ mice. On the other hand, the frequency of AT $\rightarrow \mathrm{CG}$ transversions was 3.6-times higher, and of singlebase frameshifts at mononucleotide runs 5.7-times 
higher in $\mathrm{MTH1}^{-/-}$than in $\mathrm{MTH1}^{+/+}$mice (Egashira et al., 2002). Single-base frameshifts at mononucleotide runs are a characteristic feature of MMR deficien$\mathrm{cy}$, and MMR was in fact shown to remove 8-oxodGMP incorporated from the nucleotide pool, since overexpression of hMTH1 reduced the DNA 8-oxoG level in $\mathrm{MSH}^{-/-}$cells (i.e. MMR-defective) (Colussi et al., 2002; Russo et al., 2004). Furthermore, $\mathrm{MTH1}^{-/-}$ $\mathrm{MSH}_{2}{ }^{-/}$mice in comparison with $\mathrm{MSH}^{-/-}$once had a specifically increased occurrence of GC $\rightarrow$ TA transversions, which could be induced by 2-oxodAMP incorporation opposite $\mathrm{G}$, or by erroneous incorporation of dAMP opposite 8-oxoG present in DNA (Egashira et al., 2002). Moreover, hMTH1 overexpression reduced the level of spontaneous Hprt locus mutations in the $\mathrm{MSH}^{-/-}$background, and among them the highest reduction was observed in the case of frameshifts, AT $\rightarrow$ GC transitions and AT $\rightarrow$ $\mathrm{TA}$ and GC $\rightarrow$ TA transversions (Russo et al., 2004). The AT $\rightarrow$ TA and GC $\rightarrow$ TA transversions are induced by erroneous incorporation of dAMP and dCMP, respectively, opposite template 2-oxoA (Kamiya \& Kasai, 1997a; 1997b; Barone et al., 2007). Consistently, MMR could be involved in 2-oxoA removal, since MutS $\alpha$ has been shown to bind 2-oxoA-containing DNA (Barone et al., 2007). Therefore, the low level of spontaneous mutations in $\mathrm{MTH}^{-/-}$mice and mouse cultured cells can be attributed partially to the removal, by the MMR system, of oxidized bases incorporated from the nucleotide pool. Furthermore, in the $\mathrm{MTH}^{-/-}$background the high level of oxidized bases incorporated to DNA from the nucleotide pool may partially sequester MMR, leading to a more frequent occurrence of single-base frameshifts at mononucleotide runs (Egashira et al., 2002). Surprisingly, $\mathrm{AT} \rightarrow \mathrm{CG}$ transversions, which are dramatically increased in mutT E. coli cells, were only slightly increased in $\mathrm{MTH1}^{-/-}$mice (Egashira et al., 2002), and only slightly decreased by hMTH1 overexpression in $\mathrm{MSH}^{-/-}$mice (Russo et al., 2004). AT $\rightarrow \mathrm{CG}$ transversions are induced by 8-oxodGMP incorporation opposite template A, and in mutT E. coli cells, lacking the MutT protein which removes both 8-oxodGTP and 8-oxodGDP, they can be much more frequent than in $\mathrm{MTH1}^{-/}$cells, lacking the 8-oxodGTP-hydrolysing MTH1 protein, but still possessing the MTH2 and NUDT5 proteins dephosphorylating 8-oxodGTP and 8-oxodGDP, respectively. On the other hand, $\mathrm{MTH}^{-/-}$mice showed increased levels of all types of mutations connected with 2-oxoA, consistently with the fact that human MTH1 hydrolyses 2-oxodATP (Russo et al., 2004). This may suggest that MTH1 is the only protein specifically involved in 2-oxodATP elimination from the mammalian cellular nucleotide pool or that 2-oxoA repair by MYH glycosylase (Ohtsubo et al., 2000) or MMR is saturated upon MTH1 deficiency.

\section{REFERENCES}

Aaltonen LA, Peltomaki P, Mecklin JP, Jarvinen H, Jass JR, Green JS, Lynch HT, Watson P, Tallqvist G, Juhola M, et al. (1994) Replication errors in benign and malignant tumors from hereditary nonpolyposis colorectal cancer patients. Cancer Res 54: 1645-1648.

Acharya S, Wilson T, Gradia S, Kane MF, Guerrette S, Marsischky GT, Kolodner R, Fishel R (1996) hMSH2 forms specific mispair-binding complexes with hMSH3 and hMSH6. Proc Natl Acad Sci USA 93: 13629-13634.

Akiyama M, Maki H, Sekiguchi M, Horiuchi T (1989) A specific role of MutT protein: to prevent dG.dA mispairing in DNA replication. Proc Natl Acad Sci USA 86: 3949-3952.

Baker SM, Bronner CE, Zhang L, Plug AW, Robatzek M, Warren G, Elliott EA, Yu J, Ashley T, Arnheim N, Flavell RA, Liskay RM (1995) Male mice defective in the DNA mismatch repair gene PMS2 exhibit abnormal chromosome synapsis in meiosis. Cell 82: 309-319.

Barone F, McCulloch SD, Macpherson P, Maga G, Yamada M, Nohmi T, Minoprio A, Mazzei F, Kunkel TA, Karran P, Bignami M (2007) Replication of 2-hydroxyadenine-containing DNA and recognition by human MutSalpha. DNA Repair (Amst) 6: 355-366.

Beckman RA, Loeb LA (2006) Efficiency of carcinogenesis with and without a mutator mutation. Proc Natl Acad Sci USA 103: 14140-14145.

Bennett SE, Umar A, Oshima J, Monnat RJ Jr, Kunkel TA (1997) Mismatch repair in extracts of Werner syndrome cell lines. Cancer Res 57: 2956-2960.

Bessman MJ, Frick DN, O'Handley SF (1996) The MutT proteins or "Nudix" hydrolases, a family of versatile, widely distributed, "housecleaning" enzymes. J Biol Chem 271: 25059-25062.

Bhatnagar SK, Bessman MJ (1988) Studies on the mutator gene, mutT of Escherichia coli. Molecular cloning of the gene, purification of the gene product, and identification of a novel nucleoside triphosphatase. J Biol Chem 263: 8953-8957.

Bhatnagar SK, Bullions LC, Bessman MJ (1991) Characterization of the mutT nucleoside triphosphatase of Escherichia coli. J Biol Chem 266: 9050-9054.

Bialkowski K, Olinski R (1997) Metabolism of phosphorylated derivatives of 8-oxo-2'-deoxyguanosine. Postepy Biochem 43: 199-208 (in Polish).

Bialkowski K, Kasprzak KS (1998) A novel assay of 8-oxo2'-deoxyguanosine 5'-triphosphate pyrophosphohydrolase (8-oxo-dGTPase) activity in cultured cells and its use for evaluation of cadmium (II) inhibition of this activity. Nucleic Acids Res 26: 3194-3201.

Bialkowski K, Kasprzak KS (2000) Activity of the antimutagenic enzyme 8-oxo-2'-deoxyguanosine 5'-triphosphate pyrophosphohydrolase (8-oxo-dGTPase) in cultured chinese hamster ovary cells: effects of cell cycle, proliferation rate, and population density. Free Radic Biol Med 28: 337-344.

Bialkowski K, Kasprzak KS (2004) Cellular 8-oxo-7,8-dihydro-2'-deoxyguanosine 5 '-triphosphate pyrophosphohydrolase activity of human and mouse MTH1 proteins does not depend on the proliferation rate. Free Radic Biol Med 37: 1534-1541.

Bialkowski K, Bialkowska A, Kasprzak KS (1999a) Cadmium(II), unlike nickel(II), inhibits 8-oxo-dGTPase activity and increases 8-oxo-dG level in DNA of the rat testis, a target organ for cadmium(II) carcinogenesis. Carcinogenesis 20: 1621-1624.

Bialkowski K, Bialkowska A, Anderson LM, Kasprzak KS (1999b) Higher activity of 8-oxo-2'-deoxyguanosine 5'- 
triphosphate pyrophosphohydrolase (8-oxo-dGTPase) coincides with lower background levels of 8-oxo-2'-deoxyguanosine in DNA of fetal compared with maternal mouse organs. Free Radic Biol Med 27: 90-94.

Blackwell LJ, Wang S, Modrich P (2001) DNA chain length dependence of formation and dynamics of hMutSalpha.hMutLalpha.heteroduplex complexes. J Biol Chem 276: 33233-33240.

Blackwell LJ, Martik D, Bjornson KP, Bjornson ES, Modrich P (1998) Nucleotide-promoted release of hMutSalpha from heteroduplex DNA is consistent with an ATP-dependent translocation mechanism. J Biol Chem 273: 32055-32062.

Bocker T, Barusevicius A, Snowden T, Rasio D, Guerrette S, Robbins D, Schmidt C, Burczak J, Croce CM, Copeland T, Kovatich AJ, Fishel R (1999) hMSH5: a human MutS homologue that forms a novel heterodimer with $\mathrm{hMSH} 4$ and is expressed during spermatogenesis. Cancer Res 59: 816-822.

Bregeon D, Doddridge ZA, You HJ, Weiss B, Doetsch PW (2003) Transcriptional mutagenesis induced by uracil and 8-oxoguanine in Escherichia coli. Mol Cell 12: 959970.

Bronner CE, Baker SM, Morrison PT, Warren G, Smith LG, Lescoe MK, Kane M, Earabino C, Lipford J, Lindblom A et al. (1994) Mutation in the DNA mismatch repair gene homologue hMLH1 is associated with hereditary non-polyposis colon cancer. Nature 368: 258-261.

Brooks PJ (2002) DNA repair in neural cells: basic science and clinical implications. Mutat Res 509: 93-108.

Brown J, Brown T, Fox KR (2001) Affinity of mismatchbinding protein MutS for heteroduplexes containing different mismatches. Biochem J 354: 627-633.

Bruni R, Martin D, Jiricny J (1988) d(GATC) sequences influence Escherichia coli mismatch repair in a distancedependent manner from positions both upstream and downstream of the mismatch. Nucleic Acids Res 16: 4875-4890.

Bullions LC, Mejean V, Claverys JP, Bessman MJ (1994) Purification of the MutX protein of Streptococcus pneumoniae, a homologue of Escherichia coli MutT. Identification of a novel catalytic domain for nucleoside triphosphate pyrophosphohydrolase activity. J Biol Chem 269: 12339-12344.

Burdett V, Baitinger C, Viswanathan M, Lovett ST, Modrich P (2001) In vivo requirement for RecJ, ExoVII, ExoI, and ExoX in methyl-directed mismatch repair. Proc Natl Acad Sci USA 98: 6765-6770.

Cai JP, Kakuma T, Tsuzuki T, Sekiguchi M (1995) cDNA and genomic sequences for rat 8-oxo-dGTPase that prevents occurrence of spontaneous mutations due to oxidation of guanine nucleotides. Carcinogenesis 16: 2343-2350.

Cai JP, Ishibashi T, Takagi Y, Hayakawa H, Sekiguchi M (2003) Mouse MTH2 protein which prevents mutations caused by 8-oxoguanine nucleotides. Biochem Biophys Res Commun 305: 1073-1077.

Canales J, Pinto RM, Costas MJ, Hernandez MT, Miro A, Bernet D, Fernandez A, Cameselle JC (1995) Rat liver nucleoside diphosphosugar or diphosphoalcohol pyrophosphatases different from nucleotide pyrophosphatase or phosphodiesterase I: substrate specificities of $\mathrm{Mg}(2+)$-and/or $\mathrm{Mn}(2+)$-dependent hydrolases acting on ADP-ribose. Biochim Biophys Acta 1246: 167-177.

Cannavo E, Marra G, Sabates-Bellver J, Menigatti M, Lipkin SM, Fischer F, Cejka P, Jiricny J (2005) Expression of the MutL homologue hMLH3 in human cells and its role in DNA mismatch repair. Cancer Res 65: 1075910766.
Chao EC, Lipkin SM (2006) Molecular models for the tissue specificity of DNA mismatch repair-deficient carcinogenesis. Nucleic Acids Res 34: 840-852.

Chen C, Merrill BJ, Lau PJ, Holm C, Kolodner RD (1999) Saccharomyces cerevisiae pol30 (proliferating cell nuclear antigen) mutations impair replication fidelity and mismatch repair. Mol Cell Biol 19: 7801-7815.

Choi JH, Kim JS, Kim YC, Kim YS, Chung NH, Cho MH (2004) Comparative study of PM2.5- and PM10-induced oxidative stress in rat lung epithelial cells. J Vet Sci 5: 11-18.

Chong IW, Chang MY, Chang HC, Yu YP, Sheu CC, Tsai JR, Hung JY, Chou SH, Tsai MS, Hwang JJ, Lin SR (2006) Great potential of a panel of multiple hMTH1, SPD, ITGA11 and COL11A1 markers for diagnosis of patients with non-small cell lung cancer. Oncol Rep 16: 981-988.

Clark AB, Valle F, Drotschmann K, Gary RK, Kunkel TA (2000) Functional interaction of proliferating cell nuclear antigen with MSH2-MSH6 and MSH2-MSH3 complexes. J Biol Chem 275: 36498-36501.

Colussi C, Parlanti E, Degan P, Aquilina G, Barnes D, Macpherson P, Karran P, Crescenzi M, Dogliotti E, Bignami M (2002) The mammalian mismatch repair pathway removes DNA 8-oxodGMP incorporated from the oxidized dNTP pool. Curr Biol 12: 912-918.

Constantin N, Dzantiev L, Kadyrov FA, Modrich P (2005) Human mismatch repair: reconstitution of a nick-directed bidirectional reaction. I Biol Chem 280: 3975239761.

Cooper DL, Lahue RS, Modrich P (1993) Methyl-directed mismatch repair is bidirectional. I Biol Chem 268: 11823-11829.

Cox EC, Degnen GE, Scheppe ML (1972) Mutator gene studies in Escherichia coli: the mutS gene. Genetics 72: 551-567.

Cunningham JM, Christensen ER, Tester DJ, Kim CY, Roche PC, Burgart LJ, Thibodeau SN (1998) Hypermethylation of the hMLH1 promoter in colon cancer with microsatellite instability. Cancer Res 58: 3455-3460.

Czeczot H, Tudek B, Lambert B, Laval J, Boiteux S (1991) Escherichia coli Fpg protein and UvrABC endonuclease repair DNA damage induced by methylene blue plus visible light in vivo and in vitro. J Bacteriol 173: 34193424.

Dengg M, Garcia-Muse T, Gill SG, Ashcroft N, Boulton SJ, Nilsen H (2006) Abrogation of the CLK-2 checkpoint leads to tolerance to base-excision repair intermediates. EMBO Rep 7: 1046-1051.

Dohet C, Wagner R, Radman M (1985) Repair of defined single base-pair mismatches in Escherichia coli. Proc Natl Acad Sci USA 82: 503-505.

Drummond JT, Bellacosa A (2001) Human DNA mismatch repair in vitro operates independently of methylation status at CpG sites. Nucleic Acids Res 29: 2234-2243.

Drummond JT, Genschel J, Wolf E, Modrich P (1997) DHFR/MSH3 amplification in methotrexate-resistant cells alters the hMutSalpha/hMutSbeta ratio and reduces the efficiency of base-base mismatch repair. Proc Natl Acad Sci USA 94: 10144-10149.

Drummond JT, Li GM, Longley MJ, Modrich P (1995) Isolation of an hMSH2-p160 heterodimer that restores DNA mismatch repair to tumor cells. Science 268: 19091912.

Duckett DR, Drummond JT, Murchie AI, Reardon JT, Sancar A, Lilley DM, Modrich P (1996) Human MutSalpha recognizes damaged DNA base pairs containing O6methylguanine, O4-methylthymine, or the cisplatind(GpG) adduct. Proc Natl Acad Sci USA 93: 6443-6447. 
Dzantiev L, Constantin N, Genschel J, Iyer RR, Burgers PM, Modrich P (2004) A defined human system that supports bidirectional mismatch-provoked excision. Mol Cell 15: 31-41.

Echols H, Lu C, Burgers PM (1983) Mutator strains of Escherichia coli, mutD and dnaQ, with defective exonucleolytic editing by DNA polymerase III holoenzyme. Proc Natl Acad Sci USA 80: 2189-2192.

Egashira A, Yamauchi K, Yoshiyama K, Kawate H, Katsuki M, Sekiguchi M, Sugimachi K, Maki H, Tsuzuki $\mathrm{T}$ (2002) Mutational specificity of mice defective in the MTH1 and/or the MSH2 genes. DNA Repair (Amst) 1: 881-893.

el-Hajj HH, Zhang H, Weiss B (1988) Lethality of a dut (deoxyuridine triphosphatase) mutation in Escherichia coli. J Bacteriol 170: 1069-1075.

Esteller M, Levine R, Baylin SB, Ellenson LH, Herman JG (1998) MLH1 promoter hypermethylation is associated with the microsatellite instability phenotype in sporadic endometrial carcinomas. Oncogene 17: 2413-2417.

Feng WY, Lee EH, Hays JB (1991) Recombinagenic processing of UV-light photoproducts in nonreplicating phage DNA by the Escherichia coli methyl-directed mismatch repair system. Genetics 129: 1007-1020.

Fishel R, Lescoe MK, Rao MR, Copeland NG, Jenkins NA, Garber J, Kane M, Kolodner R (1993) The human mutator gene homolog MSH2 and its association with hereditary nonpolyposis colon cancer. Cell 75: 1027-1038.

Flores-Rozas H, Clark D, Kolodner RD (2000) Proliferating cell nuclear antigen and Msh2p-Msh6p interact to form an active mispair recognition complex. Nat Genet 26: 375-378.

Fowler RG, White SJ, Koyama C, Moore SC, Dunn RL, Schaaper RM (2003) Interactions among the Escherichia coli mutT, mutM, and mutY damage prevention pathways. DNA Repair (Amst) 2: 159-173.

Fujikawa K, Kamiya H, Yakushiji H, Fujii Y, Nakabeppu Y, Kasai H (1999) The oxidized forms of dATP are substrates for the human MutT homologue, the hMTH1 protein. J Biol Chem 274: 18201-18205.

Fujikawa K, Yakushiji H, Nakabeppu Y, Suzuki T, Masuda M, Ohshima H, Kasai H (2002) 8-Chloro-dGTP, a hypochlorous acid-modified nucleotide, is hydrolyzed by hMTH1, the human MutT homolog. FEBS Lett 512: 149-151.

Funchain P, Yeung A, Stewart JL, Lin R, Slupska MM, Miller JH (2000) The consequences of growth of a mutator strain of Escherichia coli as measured by loss of function among multiple gene targets and loss of fitness. Genetics 154: 959-970.

Furuichi M, Yoshida MC, Oda H, Tajiri T, Nakabeppu Y, Tsuzuki T, Sekiguchi M (1994) Genomic structure and chromosome location of the human mutT homologue gene MTH1 encoding 8-oxo-dGTPase for prevention of A: $T$ to $C: G$ transversion. Genomics 24: 485-490.

Furuta A, Iida T, Nakabeppu Y, Iwaki T (2001) Expression of hMTH1 in the hippocampi of control and Alzheimer's disease. Neuroreport 12: 2895-2899.

Gadsden MH, McIntosh EM, Game JC, Wilson PJ, Haynes RH (1993) dUTP pyrophosphatase is an essential enzyme in Saccharomyces cerevisiae. EMBO J 12: 4425-4431.

Gasmi L, Cartwright JL, McLennan AG (1999) Cloning, expression and characterization of $\mathrm{YSA} 1 \mathrm{H}$, a human adenosine 5 '-diphosphosugar pyrophosphatase possessing a MutT motif. Biochem J 344 Pt 2: 331-337.

Genschel J, Modrich P (2003) Mechanism of 5'-directed excision in human mismatch repair. Mol Cell 12: 10771086.
Genschel J, Bazemore LR, Modrich P (2002) Human exonuclease I is required for $5^{\prime}$ and $3^{\prime}$ mismatch repair. $J$ Biol Chem 277: 13302-13311.

Genschel J, Littman SI, Drummond JT, Modrich P (1998) Isolation of MutSbeta from human cells and comparison of the mismatch repair specificities of MutSbeta and MutSalpha. J Biol Chem 273: 19895-19901.

Glickman BW (1979) Spontaneous mutagenesis in Escherichia coli strains lacking 6-methyladenine residues in their DNA: an altered mutational spectrum in dammutants. Mutat Res 61: 153-162.

Gomes-Pereira M, Fortune MT, Ingram L, McAbney JP, Monckton DG (2004) Pms2 is a genetic enhancer of trinucleotide CAG.CTG repeat somatic mosaicism: implications for the mechanism of triplet repeat expansion. Hum Mol Genet 13: 1815-1825.

Gradia S, Acharya S, Fishel R (1997) The human mismatch recognition complex hMSH2-hMSH6 functions as a novel molecular switch. Cell 91: 995-1005.

Gradia S, Subramanian D, Wilson T, Acharya S, Makhov A, Griffith J, Fishel R (1999) hMSH2-hMSH6 forms a hydrolysis-independent sliding clamp on mismatched DNA. Mol Cell 3: 255-261.

Grilley M, Griffith J, Modrich P (1993) Bidirectional excision in methyl-directed mismatch repair. J Biol Chem 268: 11830-11837.

Grilley M, Welsh KM, Su SS, Modrich P (1989) Isolation and characterization of the Escherichia coli mutL gene product. J Biol Chem 264: 1000-1004.

Gu L, Hong Y, McCulloch S, Watanabe H, Li GM (1998) ATP-dependent interaction of human mismatch repair proteins and dual role of PCNA in mismatch repair. Nucleic Acids Res 26: 1173-1178.

Guillet M, Van Der Kemp PA, Boiteux S (2006) dUTPase activity is critical to maintain genetic stability in Saccharomyces cerevisiae. Nucleic Acids Res 34: 2056-2066.

Guo S, Presnell SR, Yuan F, Zhang Y, Gu L, Li GM (2004) Differential requirement for proliferating cell nuclear antigen in $5^{\prime}$ and $3^{\prime}$ nick-directed excision in human mismatch repair. J Biol Chem 279: 16912-16917.

Haghdoost S, Sjolander L, Czene S, Harms-Ringdahl M (2006) The nucleotide pool is a significant target for oxidative stress. Free Radic Biol Med 41: 620-626.

Haghdoost S, Czene S, Naslund I, Skog S, Harms-Ringdahl M (2005) Extracellular 8-oxo-dG as a sensitive parameter for oxidative stress in vivo and in vitro. Free Radic Res 39: 153-162.

Harfe BD, Jinks-Robertson S (2000) Mismatch repair proteins and mitotic genome stability. Mutat Res 451: 151167.

Hayakawa H, Taketomi A, Sakumi K, Kuwano M, Sekiguchi M (1995) Generation and elimination of 8-oxo7,8-dihydro-2'-deoxyguanosine 5'-triphosphate, a mutagenic substrate for DNA synthesis, in human cells. Biochemistry 34: 89-95.

Hayakawa H, Hofer A, Thelander L, Kitajima S, Cai Y, Oshiro S, Yakushiji H, Nakabeppu Y, Kuwano M, Sekiguchi M (1999) Metabolic fate of oxidized guanine ribonucleotides in mammalian cells. Biochemistry 38: 3610-3614.

Her C, Doggett NA (1998) Cloning, structural characterization, and chromosomal localization of the human orthologue of Saccharomyces cerevisiae MSH5 gene. Genomics 52: 50-61.

Herman JG, Umar A, Polyak K, Graff JR, Ahuja N, Issa JP, Markowitz S, Willson JK, Hamilton SR, Kinzler KW, Kane MF, Kolodner RD, Vogelstein B, Kunkel TA, Baylin SB (1998) Incidence and functional consequences of 
hMLH1 promoter hypermethylation in colorectal carcinoma. Proc Natl Acad Sci USA 95: 6870-6875.

Hibi K, Liu Q, Beaudry GA, Madden SL, Westra WH, Wehage SL, Yang SC, Heitmiller RF, Bertelsen AH, Sidransky D, Jen J (1998) Serial analysis of gene expression in non-small cell lung cancer. Cancer Res 58: 5690-5694.

Hollingsworth NM, Ponte L, Halsey C (1995) MSH5, a novel MutS homolog, facilitates meiotic reciprocal recombination between homologs in Saccharomyces cerevisiae but not mismatch repair. Genes Dev 9: 1728-1739.

Holmes J Jr, Clark S, Modrich P (1990) Strand-specific mismatch correction in nuclear extracts of human and Drosophila melanogaster cell lines. Proc Natl Acad Sci USA 87: 5837-5841.

Horii A, Han HJ, Sasaki S, Shimada M, Nakamura Y (1994) Cloning, characterization and chromosomal assignment of the human genes homologous to yeast PMS1, a member of mismatch repair genes. Biochem Biophys Res Commun 204: 1257-1264.

Hughes MJ, Jiricny J (1992) The purification of a human mismatch-binding protein and identification of its associated ATPase and helicase activities. J Biol Chem 267: 23876-23882.

Iams K, Larson ED, Drummond JT (2002) DNA template requirements for human mismatch repair in vitro. J Biol Chem 277: 30805-30814.

Igarashi $\mathrm{H}$, Tsuzuki T, Kakuma T, Tominaga Y, Sekiguchi M (1997) Organization and expression of the mouse MTH1 gene for preventing transversion mutation. J Biol Chem 272: 3766-3772.

Iida T, Furuta A, Nakabeppu Y, Iwaki T (2004) Defense mechanism to oxidative DNA damage in glial cells. Neuropathology 24: 125-130.

Iida T, Furuta A, Kawashima M, Nishida J, Nakabeppu Y, Iwaki T (2001) Accumulation of 8-oxo-2'-deoxyguanosine and increased expression of hMTH1 protein in brain tumors. Neuro-oncol 3: 73-81.

Imoto S, Patro JN, Jiang YL, Oka N, Greenberg MM (2006) Synthesis, DNA polymerase incorporation, and enzymatic phosphate hydrolysis of formamidopyrimidine nucleoside triphosphates. J Am Chem Soc 128: 1460614611.

Inokuchi K, Ikejima M, Watanabe A, Nakajima E, Orimo H, Nomura T, Shimada T (1995) Loss of expression of the human MSH3 gene in hematological malignancies. Biochem Biophys Res Commun 214: 171-179.

Inoue M, Kamiya H, Fujikawa K, Ootsuyama Y, MurataKamiya N, Osaki T, Yasumoto K, Kasai H (1998) Induction of chromosomal gene mutations in Escherichia coli by direct incorporation of oxidatively damaged nucleotides. New evaluation method for mutagenesis by damaged DNA precursors in vivo. J Biol Chem 273: 11069-11074.

Ishibashi T, Hayakawa H, Sekiguchi M (2003) A novel mechanism for preventing mutations caused by oxidation of guanine nucleotides. EMBO Rep 4: 479-483.

Ishibashi T, Hayakawa H, Ito R, Miyazawa M, Yamagata Y, Sekiguchi M (2005) Mammalian enzymes for preventing transcriptional errors caused by oxidative damage. Nucleic Acids Res 33: 3779-3784.

Ito R, Hayakawa H, Sekiguchi M, Ishibashi T (2005) Multiple enzyme activities of Escherichia coli MutT protein for sanitization of DNA and RNA precursor pools. Biochemistry 44: 6670-6674.

Iyer RR, Pluciennik A, Burdett V, Modrich PL (2006) DNA mismatch repair: functions and mechanisms. Chem Rev 106: 302-323.
Jass JR (2006) Hereditary non-polyposis colorectal cancer: the rise and fall of a confusing term. World J Gastroenterol 12: 4943-4950.

Jiang GF, Zhuang ZX, Liu QZ, Xu L, He Y, Du LT (2005) Genetic polymorphisms of nucleotide repair gene hMTH1 in southern Chinese Han population. Yi Chuan 27: 25-29.

Jiricny J (2006) The multifaceted mismatch-repair system. Nat Rev Mol Cell Biol 7: 335-346.

Johnson KA, Mierzwa ML, Fink SP, Marnett LJ (1999) MutS recognition of exocyclic DNA adducts that are endogenous products of lipid oxidation. J Biol Chem 274: 27112-27118.

Johnson RE, Kovvali GK, Guzder SN, Amin NS, Holm C, Habraken Y, Sung P, Prakash L, Prakash S (1996) Evidence for involvement of yeast proliferating cell nuclear antigen in DNA mismatch repair. J Biol Chem 271: 27987-27990.

Jones M, Wagner R, Radman M (1987) Repair of a mismatch is influenced by the base composition of the surrounding nucleotide sequence. Genetics 115: 605-610.

Kadyrov FA, Dzantiev L, Constantin N, Modrich P (2006) Endonucleolytic function of MutLalpha in human mismatch repair. Cell 126: 297-308.

Kajitani K, Yamaguchi H, Dan Y, Furuichi M, Kang D, Nakabeppu Y (2006) MTH1, an oxidized purine nucleoside triphosphatase, suppresses the accumulation of oxidative damage of nucleic acids in the hippocampal microglia during kainate-induced excitotoxicity. J Neurosci 26: 1688-1698.

Kakuma T, Nishida J, Tsuzuki T, Sekiguchi M (1995) Mouse MTH1 protein with 8-oxo-7,8-dihydro-2'-deoxyguanosine $5^{\prime}$-triphosphatase activity that prevents transversion mutation. cDNA cloning and tissue distribution. J Biol Chem 270: 25942-25948.

Kamath AV, Yanofsky C (1993) Sequence and characterization of mutT from Proteus vulgaris. Gene 134: 99-102.

Kamiya H, Kasai H (1995) Formation of 2-hydroxydeoxyadenosine triphosphate, an oxidatively damaged nucleotide, and its incorporation by DNA polymerases. Steady-state kinetics of the incorporation. J Biol Chem 270: 19446-19450.

Kamiya H, Kasai H (1997a) Mutations induced by 2-hydroxyadenine on a shuttle vector during leading and lagging strand syntheses in mammalian cells. Biochemistry 36: 11125-11130.

Kamiya H, Kasai H (1997b) Substitution and deletion mutations induced by 2-hydroxyadenine in Escherichia coli: effects of sequence contexts in leading and lagging strands. Nucleic Acids Res 25: 304-311.

Kamiya H, Kasai H (1999) Preparation of 8-hydroxy-dGTP and 2-hydroxy-dATP by a phosphate transfer reaction by nucleoside diphosphate kinase. Nucl Nucl 18: 307-310.

Kamiya H, Yakushiji H, Dugue L, Tanimoto M, Pochet S, Nakabeppu Y, Harashima H (2004) Probing the substrate recognition mechanism of the human MTH1 protein by nucleotide analogs. J Mol Biol 336: 843-850.

Kane MF, Loda M, Gaida GM, Lipman J, Mishra R, Goldman H, Jessup JM, Kolodner R (1997) Methylation of the hMLH1 promoter correlates with lack of expression of hMLH1 in sporadic colon tumors and mismatch repair-defective human tumor cell lines. Cancer Res 57: 808-811.

Kang D, Nishida J, Iyama A, Nakabeppu Y, Furuichi M, Fujiwara T, Sekiguchi M, Takeshige K (1995) Intracellular localization of 8-oxo-dGTPase in human cells, with special reference to the role of the enzyme in mitochondria. J Biol Chem 270: 14659-14665. 
Kasprzak KS, Nakabeppu Y, Kakuma T, Sakai Y, Tsuruya K, Sekiguchi M, Ward JM, Diwan BA, Nagashima K, Kasprzak BH (2001) Intracellular distribution of the antimutagenic enzyme MTH1 in the liver, kidney and testis of F344 rats and its modulation by cadmium. Exp Toxicol Pathol 53: 325-335.

Kennedy CH, Pass HI, Mitchell JB (2003) Expression of human MutT homologue (hMTH1) protein in primary non-small-cell lung carcinomas and histologically normal surrounding tissue. Free Radic Biol Med 34: 14471457.

Kennedy CH, Cueto R, Belinsky SA, Lechner JF, Pryor WA (1998) Overexpression of hMTH1 mRNA: a molecular marker of oxidative stress in lung cancer cells. FEBS Lett 429: 17-20.

Kikuchi H, Furuta A, Nishioka K, Suzuki SO, Nakabeppu $Y$, Iwaki T (2002) Impairment of mitochondrial DNA repair enzymes against accumulation of 8-oxo-guanine in the spinal motor neurons of amyotrophic lateral sclerosis. Acta Neuropathol (Berl) 103: 408-414.

Kim HN, Morimoto Y, Tsuda T, Ootsuyama Y, Hirohashi M, Hirano T, Tanaka I, Lim Y, Yun IG, Kasai H (2001) Changes in DNA 8-hydroxyguanine levels, 8-hydroxyguanine repair activity, and hOGG1 and hMTH1 mRNA expression in human lung alveolar epithelial cells induced by crocidolite asbestos. Carcinogenesis 22: 265-269.

Kim IJ, Ku JL, Kang HC, Park JH, Yoon KA, Shin Y, Park HW, Jang SG, Lim SK, Han SY, Shin YK, Lee MR, Jeong SY, Shin HR, Lee JS, Kim WH, Park JG (2004) Mutational analysis of OGG1, MYH, MTH1 in FAP, HNPCC and sporadic colorectal cancer patients: R154H OGG1 polymorphism is associated with sporadic colorectal cancer patients. Hum Genet 115: 498-503.

Kim JE, Hyun JW, Hayakawa H, Choi S, Choi J, Chung $\mathrm{MH}$ (2006) Exogenous 8-oxo-dG is not utilized for nucleotide synthesis but enhances the accumulation of 8oxo-Gua in DNA through error-prone DNA synthesis. Mutat Res 596: 128-136.

Kim JS, Kim WY, Rho HW, Park JW, Park BH, Han MK, Kim UH, Kim HR (1998) Purification and characterization of adenosine diphosphate ribose pyrophosphatase from human erythrocytes. Int J Biochem Cell Biol 30: 629-638.

Kimura Y, Oda S, Egashira A, Kakeji Y, Baba H, Nakabeppu Y, Maehara Y (2004) A variant form of hMTH1, a human homologue of the E. coli mutT gene, correlates with somatic mutation in the p53 tumour suppressor gene in gastric cancer patients. J Med Genet 41: e57.

Kleczkowska HE, Marra G, Lettieri T, Jiricny J (2001) hMSH3 and hMSH6 interact with PCNA and colocalize with it to replication foci. Genes Dev 15: 724-736.

Kneitz B, Cohen PE, Avdievich E, Zhu L, Kane MF, Hou H Jr, Kolodner RD, Kucherlapati R, Pollard JW, Edelmann W (2000) MutS homolog 4 localization to meiotic chromosomes is required for chromosome pairing during meiosis in male and female mice. Genes Dev 14: 1085-1097.

Kohno T, Sakiyama T, Kunitoh H, Goto K, Nishiwaki Y, Saito D, Hirose H, Eguchi T, Yanagitani N, Saito R, Sasaki-Matsumura R, Mimaki S, Toyama K, Yamamoto S, Kuchiba A, Sobue T, Ohta T, Ohki M, Yokota J (2006) Association of polymorphisms in the MTH1 gene with small cell lung carcinoma risk. Carcinogenesis 27: 24482454.

Koketsu S, Watanabe T, Nagawa H (2004) Expression of DNA repair protein: MYH, NTH1, and MTH1 in colorectal cancer. Hepatogastroenterology 51: 638-642.
Kolodner RD, Tytell JD, Schmeits JL, Kane MF, Gupta RD, Weger J, Wahlberg S, Fox EA, Peel D, Ziogas A, Garber JE, Syngal S, Anton-Culver H, Li FP (1999) Germline msh6 mutations in colorectal cancer families. Cancer Res 59: 5068-5074.

Koonin EV (1993) A highly conserved sequence motif defining the family of MutT-related proteins from eubacteria, eukaryotes and viruses. Nucleic Acids Res 21: 4847.

Koivisto P, Duncan T, Lindahl T, Sedgwick B (2003) Minimal methylated substrate and extended substrate range of Escherichia coli AlkB protein, a 1-methyladenineDNA dioxygenase. J Biol Chem 278: 44348-44354.

Kovtun IV, McMurray CT (2001) Trinucleotide expansion in haploid germ cells by gap repair. Nat Genet 27: 407411.

Kramer B, Kramer W, Fritz HJ (1984) Different base/base mismatches are corrected with different efficiencies by the methyl-directed DNA mismatch-repair system of $E$. coli. Cell 38: 879-887.

Kramer W, Kramer B, Williamson MS, Fogel S (1989) Cloning and nucleotide sequence of DNA mismatch repair gene PMS1 from Saccharomyces cerevisiae: homology of PMS1 to procaryotic MutL and HexB. J Bacteriol 171: 5339-5346.

Krokan HE, Kavli B, Slupphaug G (2004) Novel aspects of macromolecular repair and relationship to human disease. J Mol Med 82: 280-297.

Krwawicz J, Arczewska KD, Speina E, Maciejewska A, Grzesiuk E (2007) Bacterial DNA repair genes and their eukaryotic homologues: 1. Mutations in genes involved in base excision repair (BER) and DNA-end processors and their implication in mutagenesis and human disease. Acta Biochim Polon 54: 413-434.

Kunkel TA, Erie DA (2005) DNA mismatch repair. Annu Rev Biochem 74: 681-710.

Kuwano K, Nakashima N, Inoshima I, Hagimoto N, Fujita M, Yoshimi M, Maeyama T, Hamada N, Watanabe K, Hara N (2003) Oxidative stress in lung epithelial cells from patients with idiopathic interstitial pneumonias. Eur Respir J 21: 232-240.

Lahue RS, Au KG, Modrich P (1989) DNA mismatch correction in a defined system. Science 245: 160-164.

Langland G, Kordich J, Creaney J, Goss KH, LillardWetherell K, Bebenek K, Kunkel TA, Groden J (2001) The Bloom's syndrome protein (BLM) interacts with MLH1 but is not required for DNA mismatch repair. $J$ Biol Chem 276: 30031-30035.

Lau PJ, Kolodner RD (2003) Transfer of the MSH2.MSH6 complex from proliferating cell nuclear antigen to mispaired bases in DNA. J Biol Chem 278: 14-17.

Lau PJ, Flores-Rozas H, Kolodner RD (2002) Isolation and characterization of new proliferating cell nuclear antigen (POL30) mutator mutants that are defective in DNA mismatch repair. Mol Cell Biol 22: 6669-6680.

Leach FS, Nicolaides NC, Papadopoulos N, Liu B, Jen J, Parsons R, Peltomaki P, Sistonen P, Aaltonen LA, Nystrom-Lahti M et al. (1993) Mutations of a mutS homolog in hereditary nonpolyposis colorectal cancer. Cell 75: 1215-1225.

Lee Bi BI, Nguyen LH, Barsky D, Fernandes M, Wilson DM, 3rd (2002) Molecular interactions of human Exo1 with DNA. Nucleic Acids Res 30: 942-949.

Lee DF, Drouin R, Pitsikas P, Rainbow AJ (2004) Detection of an involvement of the human mismatch repair genes hMLH1 and hMSH2 in nucleotide excision repair is dependent on UVC fluence to cells. Cancer Res 64: 3865-3870. 
Lee SD, Alani E (2006) Analysis of interactions between mismatch repair initiation factors and the replication processivity factor PCNA. J Mol Biol 355: 175-184.

Li GM, Modrich P (1995) Restoration of mismatch repair to nuclear extracts of $\mathrm{H} 6$ colorectal tumor cells by a heterodimer of human MutL homologs. Proc Natl Acad Sci USA 92: 1950-1954.

Li GM, Wang H, Romano LJ (1996) Human MutSalpha specifically binds to DNA containing aminofluorene and acetylaminofluorene adducts. J Biol Chem 271: 24084-24088.

Lin YL, Shivji MK, Chen C, Kolodner R, Wood RD, Dutta A (1998a) The evolutionarily conserved zinc finger motif in the largest subunit of human replication protein $A$ is required for DNA replication and mismatch repair but not for nucleotide excision repair. J Biol Chem 273: 1453-1461.

Lin YW, Kubota M, Koishi S, Sawada M, Usami I, Watanabe K, Akiyama Y (1998b) Analysis of mutations at the DNA repair genes in acute childhood leukaemia. $\mathrm{Br} J$ Haematol 103: 462-466.

Lipkin SM, Wang V, Jacoby R, Banerjee-Basu S, Baxevanis AD, Lynch HT, Elliott RM, Collins FS (2000) MLH3: a DNA mismatch repair gene associated with mammalian microsatellite instability. Nat Genet 24: 27-35.

Lipkin SM, Moens PB, Wang V, Lenzi M, Shanmugarajah D, Gilgeous A, Thomas J, Cheng J, Touchman JW, Green ED, Schwartzberg P, Collins FS, Cohen PE (2002) Meiotic arrest and aneuploidy in MLH3-deficient mice. Nat Genet 31: 385-390.

Liu K, Niu L, Linton JP, Crouse GF (1994) Characterization of the mouse Rep-3 gene: sequence similarities to bacterial and yeast mismatch-repair proteins. Gene 147: 169-177.

Liu Z, Wang LE, Strom SS, Spitz MR, Babaian RJ, DiGiovanni J, Wei Q (2003) Overexpression of hMTH in peripheral lymphocytes and risk of prostate cancer: a case-control analysis. Mol Carcinog 36: 123-129.

Loeb LA (2001) A mutator phenotype in cancer. Cancer Res 61: 3230-3239.

Lopez de Saro FJ, O'Donnell M (2001) Interaction of the beta sliding clamp with MutS, ligase, and DNA polymerase I. Proc Natl Acad Sci USA 98: 8376-8380.

Lynch HT, de la Chapelle A (1999) Genetic susceptibility to non-polyposis colorectal cancer. J Med Genet 36: 801-818.

Lyons SM, Schendel PF (1984) Kinetics of methylation in Escherichia coli K-12. J Bacteriol 159: 421-423.

Macpherson P, Barone F, Maga G, Mazzei F, Karran P, Bignami M (2005) 8-oxoguanine incorporation into DNA repeats in vitro and mismatch recognition by MutSalpha. Nucleic Acids Res 33: 5094-5105.

Maddukuri L, Dudzińska D, Tudek B (2007) Bacterial DNA repair genes and their eukaryotic homologues: 4 . The role of nucleotide excision DNA repair (NER) system in mammalian cells. Acta Biochim Polon 54: 469-482.

Maki H, Sekiguchi M (1992) MutT protein specifically hydrolyses a potent mutagenic substrate for DNA synthesis. Nature 355: 273-275.

Manley K, Shirley TL, Flaherty L, Messer A (1999) Msh2 deficiency prevents in vivo somatic instability of the CAG repeat in Huntington disease transgenic mice. Nat Genet 23: 471-473.

Marsischky GT, Filosi N, Kane MF, Kolodner R (1996) Redundancy of Saccharomyces cerevisiae MSH3 and MSH6 in MSH2-dependent mismatch repair. Genes Dev 10: 407-420.

Martik D, Baitinger C, Modrich P (2004) Differential specificities and simultaneous occupancy of human MutS- alpha nucleotide binding sites. I Biol Chem 279: $28402-$ 28410.

Matic I, Radman M, Taddei F, Picard B, Doit C, Bingen E, Denamur E, Elion J (1997) Highly variable mutation rates in commensal and pathogenic Escherichia coli. Science 277: 1833-1834.

Mazurek A, Berardini M, Fishel R (2002) Activation of human MutS homologs by 8-oxo-guanine DNA damage. J Biol Chem 277: 8260-8266.

McCulloch SD, Gu L, Li GM (2003) Bi-directional processing of DNA loops by mismatch repair-dependent and independent pathways in human cells. J Biol Chem 278: 3891-3896.

McLennan AG (2006) The Nudix hydrolase superfamily. Cell Mol Life Sci 63: 123-143.

Mejean V, Salles C, Bullions LC, Bessman MJ, Claverys JP (1994) Characterization of the mutX gene of Streptococcus pneumoniae as a homologue of Escherichia coli mut $\mathrm{T}$, and tentative definition of a catalytic domain of the dGTP pyrophosphohydrolases. Mol Microbiol 11: 323-330.

Mello JA, Acharya S, Fishel R, Essigmann JM (1996) The mismatch-repair protein $\mathrm{hMSH} 2$ binds selectively to DNA adducts of the anticancer drug cisplatin. Chem Biol 3: 579-589.

Meyer F, Fiala E, Westendorf J (2000) Induction of 8-oxodGTPase activity in human lymphoid cells and normal fibroblasts by oxidative stress. Toxicology 146: 83-92.

Michaels ML, Miller JH (1992) The GO system protects organisms from the mutagenic effect of the spontaneous lesion 8-hydroxyguanine (7,8-dihydro-8-oxoguanine). J Bacteriol 174: 6321-6325.

Miller H, Prasad R, Wilson SH, Johnson F, Grollman AP (2000) 8-oxodGTP incorporation by DNA polymerase beta is modified by active-site residue Asn279. Biochemistry 39: 1029-1033.

Miller JH (1996) Spontaneous mutators in bacteria: insights into pathways of mutagenesis and repair. Annu Rev Microbiol 50: 625-643.

Minnick DT, Pavlov YI, Kunkel TA (1994) The fidelity of the human leading and lagging strand DNA replication apparatus with 8-oxodeoxyguanosine triphosphate. Nucleic Acids Res 22: 5658-5664.

Mishima M, Sakai Y, Itoh N, Kamiya H, Furuichi M, Takahashi M, Yamagata Y, Iwai S, Nakabeppu Y, Shirakawa M (2004) Structure of human MTH1, a Nudix family hydrolase that selectively degrades oxidized purine nucleoside triphosphates. I Biol Chem 279: 33806-33815.

Miyako K, Kohno H, Ihara K, Kuromaru R, Matsuura N, Hara T (2004) Association study of human MTH1 gene polymorphisms with type 1 diabetes mellitus. Endocr J 51: 493-498.

Mo JY, Maki H, Sekiguchi M (1992) Hydrolytic elimination of a mutagenic nucleotide, 8-oxodGTP, by human 18kilodalton protein: sanitization of nucleotide pool. Proc Natl Acad Sci USA 89: 11021-11025.

Modrich P (1991) Mechanisms and biological effects of mismatch repair. Annu Rev Genet 25: 229-253.

Modrich P, Lahue R (1996) Mismatch repair in replication fidelity, genetic recombination, and cancer biology. Annu Rev Biochem 65: 101-133.

Mu D, Tursun M, Duckett DR, Drummond JT, Modrich P, Sancar A (1997) Recognition and repair of compound DNA lesions (base damage and mismatch) by human mismatch repair and excision repair systems. Mol Cell Biol 17: 760-769.

Nakabeppu Y, Sakumi K, Sakamoto K, Tsuchimoto D, Tsuzuki T, Nakatsu Y (2006) Mutagenesis and carcinogen- 
esis caused by the oxidation of nucleic acids. Biol Chem 387: 373-379.

Nakahara T, Zhang QM, Hashiguchi K, Yonei S (2000) Identification of proteins of Escherichia coli and Saccharomyces cerevisiae that specifically bind to C/C mismatches in DNA. Nucleic Acids Res 28: 2551-2556.

New L, Liu K, Crouse GF (1993) The yeast gene MSH3 defines a new class of eukaryotic MutS homologues. Mol Gen Genet 239: 97-108.

Ni TT, Marsischky GT, Kolodner RD (1999) MSH2 and MSH6 are required for removal of adenine misincorporated opposite 8-oxo-guanine in S. cerevisiae. Mol Cell 4: 439-444.

Nicolaides NC, Papadopoulos N, Liu B, Wei YF, Carter KC, Ruben SM, Rosen CA, Haseltine WA, Fleischmann RD, Fraser CM et al. (1994) Mutations of two PMS homologues in hereditary nonpolyposis colon cancer. $\mathrm{Na}$ ture 371: 75-80.

Nielsen FC, Jager AC, Lutzen A, Bundgaard JR, Rasmussen LJ (2004) Characterization of human exonuclease 1 in complex with mismatch repair proteins, subcellular localization and association with PCNA. Oncogene 23: 1457-1468.

Nieminuszczy J, Grzesiuk E (2007) Bacterial DNA repair genes and their eukaryotic homologues: 3. AlkB dioxygenase and Ada methyltransferase in the direct repair of alkylated DNA. Acta Biochim Polon 54: 459-468.

Nowosielska A (2007) Bacterial DNA repair genes and their eukaryotic homologues: 5 . The role of recombination in DNA repair and genome stability. Acta Biochim Polon 54: 483-494.

Oda H, Nakabeppu Y, Furuichi M, Sekiguchi M (1997) Regulation of expression of the human MTH1 gene encoding 8-oxo-dGTPase. Alternative splicing of transcription products. J Biol Chem 272: 17843-17850.

Oda H, Taketomi A, Maruyama R, Itoh R, Nishioka K, Yakushiji H, Suzuki T, Sekiguchi M, Nakabeppu Y (1999) Multi-forms of human MTH1 polypeptides produced by alternative translation initiation and single nucleotide polymorphism. Nucleic Acids Res 27: 43354343.

O'Driscoll M, Jeggo PA (2006) The role of double-strand break repair - insights from human genetics. Nat Rev Genet 7: 45-54.

Ohtsubo T, Nishioka K, Imaiso Y, Iwai S, Shimokawa H, Oda H, Fujiwara T, Nakabeppu Y (2000) Identification of human MutY homolog (hMYH) as a repair enzyme for 2-hydroxyadenine in DNA and detection of multiple forms of hMYH located in nuclei and mitochondria. Nucleic Acids Res 28: 1355-1364.

Okamoto K, Toyokuni S, Kim WJ, Ogawa O, Kakehi Y, Arao S, Hiai H, Yoshida O (1996) Overexpression of human mutT homologue gene messenger RNA in renal-cell carcinoma: evidence of persistent oxidative stress in cancer. Int J Cancer 65: 437-441.

Okochi E, Ichimura S, Sugimura T, Ushijima T (2002a) The absence of Mth1 inactivation and DNA polymerase kappa overexpression in rat mammary carcinomas with frequent $\mathrm{A}: \mathrm{T}$ to $\mathrm{C}: \mathrm{G}$ transversions. Jpn J Cancer Res 93: 501-506.

Okochi E, Watanabe N, Sugimura T, Ushijima T (2002b) Single nucleotide instability: a wide involvement in human and rat mammary carcinogenesis? Mutat Res 506-507: 101-111.

Olinski R, Siomek A, Rozalski R, Gackowski D, Foksinski M, Guz J, Dziaman T, Szpila A, Tudek B (2007) Oxidative damage to DNA and antioxidant status in aging and age-related diseases. Acta Biochim Polon 54: 11-26.
Owen BA, Yang Z, Lai M, Gajek M, Badger JD, 2nd, Hayes JJ, Edelmann W, Kucherlapati R, Wilson TM, McMurray CT (2005) (CAG)(n)-hairpin DNA binds to Msh2Msh3 and changes properties of mismatch recognition. Nat Struct Mol Biol 12: 663-670.

Palombo F, Iaccarino I, Nakajima E, Ikejima M, Shimada T, Jiricny J (1996) hMutSbeta, a heterodimer of hMSH2 and hMSH3, binds to insertion/deletion loops in DNA. Curr Biol 6: 1181-1184.

Palombo F, Gallinari P, Iaccarino I, Lettieri T, Hughes M, D’Arrigo A, Truong O, Hsuan JJ, Jiricny J (1995) GTBP, a 160-kilodalton protein essential for mismatch-binding activity in human cells. Science 268: 1912-1914.

Papadopoulos N, Nicolaides NC, Wei YF, Ruben SM, Carter KC, Rosen CA, Haseltine WA, Fleischmann RD, Fraser CM, Adams MD, et al. (1994) Mutation of a mutL homolog in hereditary colon cancer. Science 263: 1625-1629.

Paquis-Flucklinger V, Santucci-Darmanin S, Paul R, Saunieres A, Turc-Carel C, Desnuelle C (1997) Cloning and expression analysis of a meiosis-specific MutS homolog: the human MSH4 gene. Genomics 44: 188-194.

Parker BO, Marinus MG (1992) Repair of DNA heteroduplexes containing small heterologous sequences in Escherichia coli. Proc Natl Acad Sci USA 89: 1730-1734.

Pavlov YI, Minnick DT, Izuta S, Kunkel TA (1994) DNA replication fidelity with 8-oxodeoxyguanosine triphosphate. Biochemistry 33: 4695-4701.

Pedrazzi G, Perrera C, Blaser H, Kuster P, Marra G, Davies SL, Ryu GH, Freire R, Hickson ID, Jiricny J, Stagljar I (2001) Direct association of Bloom's syndrome gene product with the human mismatch repair protein MLH1. Nucleic Acids Res 29: 4378-4386.

Peltomaki P (2005) Lynch syndrome genes. Fam Cancer 4: 227-232.

Petranovic M, Vlahovic K, Zahradka D, Dzidic S, Radman $M$ (2000) Mismatch repair in xenopus egg extracts is not strand-directed by DNA methylation. Neoplasma 47 : 375-381.

Porter DW, Yakushiji H, Nakabeppu Y, Sekiguchi M, Fivash MJ Jr, Kasprzak KS (1997) Sensitivity of Escherichia coli (MutT) and human (MTH1) 8-oxo-dGTPases to in vitro inhibition by the carcinogenic metals, nickel (II), copper (II), cobalt (II) and cadmium (II). Carcinogenesis 18: 1785-1791.

Prolla TA, Christie DM, Liskay RM (1994) Dual requirement in yeast DNA mismatch repair for MLH1 and PMS1, two homologs of the bacterial mutL gene. Mol Cell Biol 14: 407-415.

Prolla TA, Baker SM, Harris AC, Tsao JL, Yao X, Bronner $C E$, Zheng B, Gordon M, Reneker J, Arnheim N, Shibata D, Bradley A, Liskay RM (1998) Tumour susceptibility and spontaneous mutation in mice deficient in Mlh1, Pms1 and Pms2 DNA mismatch repair. Nat Genet 18: 276-279.

Purmal AA, Kow YW, Wallace SS (1994) 5-Hydroxypyrimidine deoxynucleoside triphosphates are more efficiently incorporated into DNA by exonuclease-free Klenow fragment than 8-oxopurine deoxynucleoside triphosphates. Nucleic Acids Res 22: 3930-3935.

Ramilo C, Gu L, Guo S, Zhang X, Patrick SM, Turchi JJ, Li GM (2002) Partial reconstitution of human DNA mismatch repair in vitro: characterization of the role of human replication protein A. Mol Cell Biol 22: 2037-2046.

Rasmussen LJ, Samson L (1996) The Escherichia coli MutS DNA mismatch binding protein specifically binds $\mathrm{O}(6)$-methylguanine DNA lesions. Carcinogenesis 17: 2085-2088. 
Rasmussen LJ, Rasmussen M, Lee B, Rasmussen AK, Wilson DM, 3rd, Nielsen FC, Bisgaard HC (2000) Identification of factors interacting with hMSH2 in the fetal liver utilizing the yeast two-hybrid system. In vivo interaction through the C-terminal domains of hEXO1 and $\mathrm{hMSH} 2$ and comparative expression analysis. $\mathrm{Mu}$ tat Res 460: 41-52.

Reenan RA, Kolodner RD (1992a) Isolation and characterization of two Saccharomyces cerevisiae genes encoding homologs of the bacterial HexA and MutS mismatch repair proteins. Genetics 132: 963-973.

Reenan RA, Kolodner RD (1992b) Characterization of insertion mutations in the Saccharomyces cerevisiae MSH1 and $\mathrm{MSH} 2$ genes: evidence for separate mitochondrial and nuclear functions. Genetics 132: 975-985.

Ribeiro JM, Carloto A, Costas MJ, Cameselle JC (2001) Human placenta hydrolases active on free ADP-ribose: an ADP-sugar pyrophosphatase and a specific ADP-ribose pyrophosphatase. Biochim Biophys Acta 1526: 86-94.

Ross-Macdonald P, Roeder GS (1994) Mutation of a meiosis-specific MutS homolog decreases crossing over but not mismatch correction. Cell 79: 1069-1080.

Russo MT, Blasi MF, Chiera F, Fortini P, Degan P, Macpherson P, Furuichi M, Nakabeppu Y, Karran P, Aquilina G, Bignami M (2004) The oxidized deoxynucleoside triphosphate pool is a significant contributor to genetic instability in mismatch repair-deficient cells. Mol Cell Biol 24: 465-474.

Sakai Y, Oda H, Yoshimura D, Furuichi M, Kang D, Iwai S, Hara T, Nakabeppu Y (2006) The GT to GC single nucleotide polymorphism at the beginning of an alternative exon 2C of human MTH1 gene confers an amino terminal extension that functions as a mitochondrial targeting signal. J Mol Med 84: 660-670.

Sakumi K, Furuichi M, Tsuzuki T, Kakuma T, Kawabata S, Maki H, Sekiguchi M (1993) Cloning and expression of cDNA for a human enzyme that hydrolyzes 8-oxodGTP, a mutagenic substrate for DNA synthesis. J Biol Chem 268: 23524-23530.

Sakumi K, Tominaga Y, Furuichi M, Xu P, Tsuzuki T, Sekiguchi M, Nakabeppu Y (2003) Ogg1 knockout-associated lung tumorigenesis and its suppression by Mth1 gene disruption. Cancer Res 63: 902-905.

Santucci-Darmanin S, Walpita D, Lespinasse F, Desnuelle C, Ashley T, Paquis-Flucklinger V (2000) MSH4 acts in conjunction with MLH1 during mammalian meiosis. FASEB J 14: 1539-1547.

Sato Y, Nanri H, Ohta M, Kasai H, Ikeda M (2003) Increase of human MTH1 and decrease of 8-hydroxydeoxyguanosine in leukocyte DNA by acute and chronic exercise in healthy male subjects. Biochem Biophys Res Commun 305: 333-338.

Satoh J, Kuroda Y (2000) A valine to methionine polymorphism at codon 83 in the 8 -oxo-dGTPase gene MTH1 is not associated with sporadic Parkinson's disease. Eur J Neurol 7: 673-677.

Satou K, Yamada M, Nohmi T, Harashima H, Kamiya H (2005) Mutagenesis induced by oxidized DNA precursors: roles of $\mathrm{Y}$ family DNA polymerases in Escherichia coli. Chem Res Toxicol 18: 1271-1278.

Savouret C, Brisson E, Essers J, Kanaar R, Pastink A, te Riele H, Junien C, Gourdon G (2003) CTG repeat instability and size variation timing in DNA repair-deficient mice. EMBO J 22: 2264-2273.

Schmutte C, Sadoff MM, Shim KS, Acharya S, Fishel R (2001) The interaction of DNA mismatch repair proteins with human exonuclease I. J Biol Chem 276: 33011-33018.
Schmutte C, Marinescu RC, Sadoff MM, Guerrette S, Overhauser J, Fishel R (1998) Human exonuclease I interacts with the mismatch repair protein hMSH2. Cancer Res 58: 4537-4542.

Schofield MJ, Hsieh P (2003) DNA mismatch repair: molecular mechanisms and biological function. Annu Rev Microbiol 57: 579-608.

Shigenaga MK, Gimeno CJ, Ames BN (1989) Urinary 8-hydroxy-2'-deoxyguanosine as a biological marker of in vivo oxidative DNA damage. Proc Natl Acad Sci USA 86: 9697-9701.

Shimokawa H, Fujii Y, Furuichi M, Sekiguchi M, Nakabeppu Y (2000) Functional significance of conserved residues in the phosphohydrolase module of Escherichia coli MutT protein. Nucleic Acids Res 28: 3240-3249.

Shimura-Miura H, Hattori N, Kang D, Miyako K, Nakabeppu Y, Mizuno Y (1999) Increased 8-oxo-dGTPase in the mitochondria of substantia nigral neurons in Parkinson's disease. Ann Neurol 46: 920-924.

Sieber OM, Lipton L, Crabtree M, Heinimann K, Fidalgo P, Phillips RK, Bisgaard ML, Orntoft TF, Aaltonen LA, Hodgson SV, Thomas HJ, Tomlinson IP (2003) Multiple colorectal adenomas, classic adenomatous polyposis, and germ-line mutations in MYH. $N$ Engl J Med 348: 791-799.

Slupska MM, Baikalov C, Lloyd R, Miller JH (1996) Mutator tRNAs are encoded by the Escherichia coli mutator genes mutA and mutC: a novel pathway for mutagenesis. Proc Natl Acad Sci USA 93: 4380-4385.

Snow ET, Foote RS, Mitra S (1984) Kinetics of incorporation of O6-methyldeoxyguanosine monophosphate during in vitro DNA synthesis. Biochemistry 23: 4289-4294.

Snowden T, Acharya S, Butz C, Berardini M, Fishel R (2004) hMSH4-hMSH5 recognizes Holliday junctions and forms a meiosis-specific sliding clamp that embraces homologous chromosomes. Mol Cell 15: 437-451.

Speina E, Arczewska KD, Gackowski D, Zielinska M, Siomek A, Kowalewski J, Olinski R, Tudek B, Kusmierek JT (2005) Contribution of hMTH1 to the maintenance of 8-oxoguanine levels in lung DNA of nonsmall-cell lung cancer patients. J Natl Cancer Inst 97: 384-395.

Su SS, Modrich P (1986) Escherichia coli mutS-encoded protein binds to mismatched DNA base pairs. Proc Natl Acad Sci USA 83: 5057-5061.

Su SS, Lahue RS, Au KG, Modrich P (1988) Mispair specificity of methyl-directed DNA mismatch correction in vitro. J Biol Chem 263: 6829-6835.

Svetlanov A, Cohen PE (2004) Mismatch repair proteins, meiosis, and mice: understanding the complexities of mammalian meiosis. Exp Cell Res 296: 71-79.

Taddei F, Hayakawa H, Bouton M, Cirinesi A, Matic I, Sekiguchi M, Radman M (1997) Counteraction by MutT protein of transcriptional errors caused by oxidative damage. Science 278: 128-130.

Takahashi S, Hirose M, Tamano S, Ozaki M, Orita S, Ito T, Takeuchi M, Ochi H, Fukada S, Kasai H, Shirai T (1998) Immunohistochemical detection of 8-hydroxy-2'deoxyguanosine in paraffin-embedded sections of rat liver after carbon tetrachloride treatment. Toxicol Pathol 26: $247-252$.

Takama F, Kanuma T, Wang D, Nishida JI, Nakabeppu Y, Wake N, Mizunuma H (2000) Mutation analysis of the hMTH1 gene in sporadic human ovarian cancer. Int I Oncol 17: 467-471.

Tarng DC, Liu TY, Huang TP (2004) Protective effect of vitamin $C$ on 8-hydroxy-2'-deoxyguanosine level in peripheral blood lymphocytes of chronic hemodialysis patients. Kidney Int 66: 820-831. 
Thomas DC, Roberts JD, Kunkel TA (1991) Heteroduplex repair in extracts of human HeLa cells. J Biol Chem 266: 3744-3751.

Topal MD, Baker MS (1982) DNA precursor pool: a significant target for N-methyl-N-nitrosourea in C3H/10T1/2 clone 8 cells. Proc Natl Acad Sci USA 79: 2211-2215.

Tran HT, Gordenin DA, Resnick MA (1999) The $3^{\prime}-->5^{\prime}$ exonucleases of DNA polymerases delta and epsilon and the $5^{\prime}-->3^{\prime}$ exonuclease Exo1 have major roles in postreplication mutation avoidance in Saccharomyces cerevisiae. Mol Cell Biol 19: 2000-2007.

Tran PT, Simon JA, Liskay RM (2001) Interactions of Exo1p with components of MutLalpha in Saccharomyces cerevisiae. Proc Natl Acad Sci USA 98: 9760-9765.

Tran PT, Erdeniz N, Symington LS, Liskay RM (2004) EXO1-A multi-tasking eukaryotic nuclease. DNA Repair (Amst) 3: 1549-1559.

Treffers HP, Spinelli V, Belser NO (1954) A Factor (or Mutator Gene) Influencing Mutation Rates in Escherichia coli. Proc Natl Acad Sci USA 40: 1064-1071.

Truglio JJ, Croteau DL, Van Houten B, Kisker C (2006) Prokaryotic nucleotide excision repair: the UvrABC system. Chem Rev 106: 233-252.

Tsutsui H, Ide T, Shiomi T, Kang D, Hayashidani S, Suematsu N, Wen J, Utsumi H, Hamasaki N, Takeshita A (2001) 8-oxo-dGTPase, which prevents oxidative stressinduced DNA damage, increases in the mitochondria from failing hearts. Circulation 104: 2883-2885.

Tsuzuki T, Egashira A, Kura S (2001a) Analysis of MTH1 gene function in mice with targeted mutagenesis. $\mathrm{Mu}$ tat Res 477: 71-78.

Tsuzuki T, Egashira A, Igarashi H, Iwakuma T, Nakatsuru Y, Tominaga Y, Kawate H, Nakao K, Nakamura K, Ide F, Kura S, Nakabeppu Y, Katsuki M, Ishikawa T, Sekiguchi M (2001b) Spontaneous tumorigenesis in mice defective in the MTH1 gene encoding 8-oxo-dGTPase. Proc Natl Acad Sci USA 98: 11456-11461.

Umar A, Risinger JI, Glaab WE, Tindall KR, Barrett JC, Kunkel TA (1998) Functional overlap in mismatch repair by human MSH3 and MSH6. Genetics 148: 16371646.

Umar A, Buermeyer AB, Simon JA, Thomas DC, Clark AB, Liskay RM, Kunkel TA (1996) Requirement for PCNA in DNA mismatch repair at a step preceding DNA resynthesis. Cell 87: 65-73.

Umar A, Boland CR, Terdiman JP, Syngal S, de la Chapelle A, Ruschoff J, Fishel R, Lindor NM, Burgart LJ, Hamelin R, Hamilton SR, Hiatt RA, Jass J, Lindblom A, Lynch HT, Peltomaki P, Ramsey SD, Rodriguez-Bigas MA, Vasen HF, Hawk ET, Barrett JC, Freedman AN, Srivastava S (2004) Revised Bethesda Guidelines for hereditary nonpolyposis colorectal cancer (Lynch syndrome) and microsatellite instability. I Natl Cancer Inst 96: 261-268.

van den Broek WJ, Nelen MR, Wansink DG, Coerwinkel MM, te Riele H, Groenen PJ, Wieringa B (2002) Somatic expansion behaviour of the (CTG)n repeat in myotonic dystrophy knock-in mice is differentially affected by Msh3 and Msh6 mismatch-repair proteins. Hum Mol Genet 11: 191-198.

Varlet I, Pallard C, Radman M, Moreau J, de Wind N (1994) Cloning and expression of the Xenopus and mouse Msh2 DNA mismatch repair genes. Nucleic Acids Res 22: 5723-5728.

Veigl ML, Kasturi L, Olechnowicz J, Ma AH, Lutterbaugh JD, Periyasamy S, Li GM, Drummond J, Modrich PL, Sedwick WD, Markowitz SD (1998) Biallelic inactivation of hMLH1 by epigenetic gene silencing, a novel mechanism causing human MSI cancers. Proc Natl Acad Sci USA 95: 8698-8702.

Venkatesan RN, Bielas JH, Loeb LA (2006) Generation of mutator mutants during carcinogenesis. DNA Repair (Amst) 5: 294-302.

Verma L, Kane MF, Brassett C, Schmeits J, Evans DG, Kolodner RD, Maher ER (1999) Mononucleotide microsatellite instability and germline MSH6 mutation analysis in early onset colorectal cancer. I Med Genet 36: 678-682.

Vidakovic M, Poznanovic G, Bode J (2005) DNA break repair: refined rules of an already complicated game. Biochem Cell Biol 83: 365-373.

Wagner R Jr, Meselson M (1976) Repair tracts in mismatched DNA heteroduplexes. Proc Natl Acad Sci USA 73: 4135-4139.

Wang H, Hays JB (2002) Mismatch repair in human nuclear extracts. Time courses and ATP requirements for kinetically distinguishable steps leading to tightly controlled $5^{\prime}$ to $3^{\prime}$ and aphidicolin-sensitive $3^{\prime}$ to $5^{\prime}$ mispair-provoked excision. J Biol Chem 277: 26143-26148.

Wang H, Hays JB (2003) Mismatch repair in human nuclear extracts: effects of internal DNA-hairpin structures between mismatches and excision-initiation nicks on mismatch correction and mismatch-provoked excision. J Biol Chem 278: 28686-28693.

Wang H, Hays JB (2004) Signaling from DNA mispairs to mismatch-repair excision sites despite intervening blockades. EMBO J 23: 2126-2133.

Wang H, Lawrence CW, Li GM, Hays JB (1999) Specific binding of human MSH2.MSH6 mismatch-repair protein heterodimers to DNA incorporating thymine- or uracil-containing UV light photoproducts opposite mismatched bases. J Biol Chem 274: 16894-16900.

Wani G, D'Ambrosio SM (1995) Cell type-specific expression of human 8-oxo-7,8-dihydroguanosine triphosphatase in normal breast and skin tissues in vivo. Carcinogenesis 16: 277-283.

Wani G, Milo GE, D’Ambrosio SM (1998) Enhanced expression of the 8-oxo-7,8-dihydrodeoxyguanosine triphosphatase gene in human breast tumor cells. Cancer Lett 125: 123-130.

Watanabe A, Ikejima M, Suzuki N, Shimada T (1996) Genomic organization and expression of the human MSH3 gene. Genomics 31: 311-318.

Wei K, Clark AB, Wong E, Kane MF, Mazur DJ, Parris T, Kolas NK, Russell R, Hou H Jr, Kneitz B, Yang G, Kunkel TA, Kolodner RD, Cohen PE, Edelmann W (2003) Inactivation of Exonuclease 1 in mice results in DNA mismatch repair defects, increased cancer susceptibility, and male and female sterility. Genes Dev 17: 603-614.

Welsh KM, Lu AL, Clark S, Modrich P (1987) Isolation and characterization of the Escherichia coli mutH gene product. J Biol Chem 262: 15624-15629.

Wheeler JM, Beck NE, Kim HC, Tomlinson IP, Mortensen NJ, Bodmer WF (1999) Mechanisms of inactivation of mismatch repair genes in human colorectal cancer cell lines: the predominant role of hMLH1. Proc Natl Acad Sci USA 96: 10296-10301.

Wijnen J, de Leeuw W, Vasen $H$, van der Klift H, Moller P, Stormorken A, Meijers-Heijboer H, Lindhout D, Menko F, Vossen S, Moslein G, Tops C, Brocker-Vriends A, Wu Y, Hofstra R, Sijmons R, Cornelisse C, Morreau H, Fodde R (1999) Familial endometrial cancer in female carriers of MSH6 germline mutations. Nat Genet 23: 142-144.

Winand NJ, Panzer JA, Kolodner RD (1998) Cloning and characterization of the human and Caenorhabditis el- 
egans homologs of the Saccharomyces cerevisiae MSH5 gene. Genomics 53: 69-80.

Wu C, Nagasaki H, Maruyama K, Nakabeppu Y, Sekiguchi M, Yuasa Y (1995) Polymorphisms and probable lack of mutation in a human mutT homolog, hMTH1, in hereditary nonpoliposis colorectal cancer. Biochem Biophys Res Commun 214: 1239-1245.

Xie Y, Yang H, Cunanan C, Okamoto K, Shibata D, Pan J, Barnes DE, Lindahl T, McIlhatton M, Fishel R, Miller JH (2004) Deficiencies in mouse Myh and Ogg1 result in tumor predisposition and $\mathrm{G}$ to $\mathrm{T}$ mutations in codon 12 of the K-ras oncogene in lung tumors. Cancer Res 64: 3096-3102.

Yakushiji H, Maraboeuf F, Takahashi M, Deng ZS, Kawabata S, Nakabeppu Y, Sekiguchi M (1997) Biochemical and physicochemical characterization of normal and variant forms of human MTH1 protein with antimutagenic activity. Mutat Res 384: 181-194.

Yamada M, O'Regan E, Brown R, Karran P (1997) Selective recognition of a cisplatin-DNA adduct by human mismatch repair proteins. Nucleic Acids Res 25: 491-496.

Yamaguchi H, Kajitani K, Dan Y, Furuichi M, Ohno M, Sakumi K, Kang D, Nakabeppu Y (2006) MTH1, an oxidized purine nucleoside triphosphatase, protects the dopamine neurons from oxidative damage in nucleic acids caused by 1-methyl-4-phenyl-1,2,3,6-tetrahydropyridine. Cell Death Differ 13: 551-563.
Yang H, Slupska MM, Wei YF, Tai JH, Luther WM, Xia YR, Shih DM, Chiang JH, Baikalov C, Fitz-Gibbon S, Phan IT, Conrad A, Miller JH (2000) Cloning and characterization of a new member of the Nudix hydrolases from human and mouse. J Biol Chem 275: 8844-8853.

Yanofsky C, Cox EC, Horn V (1966) The unusual mutagenic specificity of an E. Coli mutator gene. Proc Natl Acad Sci USA 55: 274-281.

Yoshimura D, Sakumi K, Ohno M, Sakai Y, Furuichi M, Iwai S, Nakabeppu Y (2003) An oxidized purine nucleoside triphosphatase, MTH1, suppresses cell death caused by oxidative stress. I Biol Chem 278: $37965-$ 37973.

Yuan F, Gu L, Guo S, Wang C, Li GM (2004) Evidence for involvement of HMGB1 protein in human DNA mismatch repair. J Biol Chem 279: 20935-20940.

Zhang Y, Yuan F, Presnell SR, Tian K, Gao Y, Tomkinson AE, Gu L, Li GM (2005) Reconstitution of 5'-directed human mismatch repair in a purified system. Cell 122: 693-705.

Zhou H, Cheng B, Lin J (2005) Expression of DNA repair enzyme hMTH1 mRNA and protein in hepatocellular carcinoma. J Huazhong Univ Sci Technolog Med Sci 25: 389-392. 